\title{
Transmitter Release from Cochlear Hair Cells Is Phase Locked to Cyclic Stimuli of Different Intensities and Frequencies
}

\author{
Juan D. Goutman \\ Instituto de Investigaciones en Ingeniería Genética y Biología Molecular, Consejo Nacional de Investigaciones Científicas y Técnicas-Universidad de Buenos \\ Aires, C1428ADN Buenos Aires, Argentina
}

\begin{abstract}
The auditory system processes time and intensity through separate brainstem pathways to derive spatial location as well as other salient features of sound. The independent coding of time and intensity begins in the cochlea, where afferent neurons can fire action potentials at constant phase throughout a wide range of stimulus intensities. We have investigated time and intensity coding by simultaneous presynaptic and postsynaptic recording at the hair cell-afferent synapse from rats. Trains of depolarizing steps to the hair cell were used to elicit postsynaptic currents that occurred at constant phase for a range of membrane potentials over which release probability varied significantly. To probe the underlying mechanisms, release was examined using single steps to various command voltages. As expected for vesicular release, first synaptic events occurred earlier as presynaptic calcium influx grew larger. However, synaptic depression produced smaller responses with longer first latencies. Thus, during repetitive hair cell stimulation, as the hair cell is more strongly depolarized, increased calcium channel gating hurries transmitter release, but the resulting vesicular depletion produces a compensatory slowing. Quantitative simulation of ribbon function shows that these two factors varied reciprocally with hair cell depolarization (stimulus intensity) to produce constant synaptic phase. Finally, we propose that the observed rapid vesicle replenishment would help maintain the vesicle pool, which in turn would equilibrate with the stimulus intensity (and therefore the number of open $\mathrm{Ca}^{2+}$ channels), so that for trains of different levels the average phase will be conserved.
\end{abstract}

\section{Introduction}

Among the acoustic features that the auditory system must represent, one of the most challenging is timing. Precise temporal processing is required for speech discrimination in humans and is also essential for the broadly conserved property of directional hearing (Ruggero, 1992; Yin, 2002).

It is well established that auditory nerve fibers are able to fire at a particular time within each cycle of a low-frequency periodic stimulus (Galambos and Davis, 1943; Kiang et al., 1965; Rose et al., 1967). Furthermore, this preferred phase can remain constant over a range of sound intensities at the characteristic frequencyphase constancy independent of intensity. Phase locking propa-

Received Jan. 31, 2012; revised Sept. 25, 2012; accepted Sept. 30, 2012.

Author contributions: J.D.G. designed research; J.D.G. performed research; J.D.G. analyzed data; J.D.G. wrote the paper.

This work was supported by Agencia Nacional de Promoción Científica y Tecnológica, Consejo Nacional de Investigaciones Científicas y Tecnológicas and National Organization for Hearing Research (to J. D. G.). Initial experiments for this project were performed at the Elisabeth Glowatzki (E.G.) Laboratory and supported by NIDCD R01006476 (to E.G.). I thank A. Belen Elgoyhen (A.B.E.) for very generous and disinterested support, E.G. and Paul A. Fuchs (P.A.F.) for initial motivation and critical support for this study, Ralf Schneggenburger, Mark Rutherford, Eleonora Katz, A. B. E., E. G., and P. A. F. for critical reading of previous versions of the manuscript, and Jimena Ballestero and Javier Zorrilla de San Martin for helpful discussions.

The author declares no conflict of interest.

Correspondence should be addressed to Juan D. Goutman, Instituto de Investigaciones en Ingeniería Genética y Biología Molecular, Consejo Nacional de Investigaciones Científicas y Técnicas-Universidad de Buenos Aires, Vuelta de Obligado 2490, C1428ADN Buenos Aires, Argentina. E-mail: goutman@dna.uba.ar.

DOI:10.1523/JNEUROSCI.0457-12.2012

Copyright $\odot 2012$ the authors $\quad 0270-6474 / 12 / 3217025-12 \$ 15.00 / 0$ gates throughout the auditory pathway supported by presynaptic and postsynaptic specializations such as calyciform synapses with large quantum contents and fast kinetics of postsynaptic receptors (Trussell, 1999; Schneggenburger and Forsythe, 2006).

The inner hair cell afferent synapse, the first synapse in the hearing pathway, is confronted with particular challenges. Synaptic contacts are small (Liberman, 1980), and while presynaptic ribbons may promote efficient vesicle resupply (Griesinger et al., 2005; Frank et al., 2010), nonetheless the readily releasable pool is several times smaller than that of calyceal terminals in the brainstem (Nouvian et al., 2006; Schneggenburger and Forsythe, 2006). Hair cell exocytosis is triggered not by temporally precise, invariant action potentials but rather by graded changes in membrane potential (Russell and Sellick, 1978), producing intracellular $\mathrm{Ca}^{2+}$ signals that vary continuously in amplitude and kinetics (Frank et al., 2009). As observed at other chemical synapses, transmitter release from the inner hair cell (IHC) ribbon synapse is $\mathrm{Ca}^{2+}$ dependent. Voltage-gated channels provide $\mathrm{Ca}^{2+}$ to drive a vesicular $\mathrm{Ca}^{2+}$ sensor that catalyzes fusion to the plasma membrane (Moser et al., 2006). Although the molecular identity of this $\mathrm{Ca}^{2+}$ sensor remains uncertain (Safieddine and Wenthold, 1999; Roux et al., 2006; Beurg et al., 2010; Johnson and Chapman, 2010; Pangrsic et al., 2010), it is highly cooperative, requiring the binding of five $\mathrm{Ca}^{2+}$ ions to trigger release, resulting in rate constants that are strongly $\mathrm{Ca}^{2+}$ dependent (Beutner et al., 2001). Thus, increasingly larger receptor potentials, driven by increasingly louder sounds, should cause more calcium influx and increas- 
ingly faster vesicular fusion (Fuchs, 2005). How then is phase constancy achieved at the hair cell ribbon synapse?

In this study, we made simultaneous recordings from IHCs and afferent boutons in an excised organ of Corti preparation and used numerical simulations to investigate the basis of transmitter release during cyclic stimuli. Using repetitive depolarizations to different frequencies and levels, we found intensityindependent, phase-locked transmitter release from the IHC ribbon synapse. However, in single-step experiments, synaptic latency shortened with greater presynaptic depolarization. This effect was offset by increased depletion of vesicular pools that slowed vesicular release at a given presynaptic depolarization. We propose that higher stimulation levels cause faster release kinetics through voltage-gated calcium influx, but also stronger depletion, which in turn reduces and thus slows transmitter release. The interplay of these two opposing actions confers phase constancy onto a given synapse. A corollary of this hypothesis is that the rate at which vesicular pools refill determines the mean quantum content during repetitive release, and therefore the firing probability of the postsynaptic afferent neuron.

\section{Materials and Methods}

Recordings of IHCs and afferent postsynaptic boutons. Excised apical turns of 9- to 11-day-old rat cochleae (Sprague Dawley, either sex) were placed into a chamber under an upright microscope (Olympus BX51WI or Axioskop2 FS plus; Zeiss) and superfused with saline at 2-3 $\mathrm{ml} / \mathrm{min}$. IHCs and contacting postsynaptic terminals were visualized on a monitor via a water immersion objective $(63 \times$ or $40 \times)$, additional magnification $(2 \times$ or $4 \times)$, difference interference contrast optics, and a camera (a CCD Rolera XR from QImaging or a Newvicon from Dage MTI). For simultaneous, paired, whole-cell, patch-clamp recordings, the postsynaptic recording was established first and the IHC recording second.

Pipette solution for isolating IHC $\mathrm{Ca}^{2+}$-currents contained (in $\mathrm{mM}$ ): $135 \mathrm{CsMeSO}_{3}, 13$ TEA Cl, 5 HEPES, $3.5 \mathrm{MgCl}_{2}, 0.1 \mathrm{CaCl}_{2}, 2.5 \mathrm{Na}_{2} \mathrm{ATP}, 1$ EGTA, pH 7.2 (CsOH); liquid junction potential (LJP), $9 \mathrm{mV}$. Postsynaptic pipette solution contained (in $\mathrm{mM}$ ): $135 \mathrm{KCl}, 3.5 \mathrm{MgCl}_{2}, 0.1 \mathrm{CaCl}_{2}$,

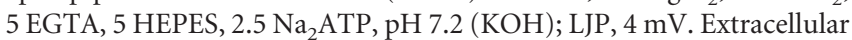
solution contained (in $\mathrm{mM}$ ): $5.8 \mathrm{KCl}, 114 \mathrm{NaCl}, 0.9 \mathrm{MgCl}_{2}, 1.3 \mathrm{CaCl}_{2}, 0.7$ $\mathrm{NaH}_{2} \mathrm{PO}_{4}$, 5.6 D- glucose, 10 HEPES, 30 TEA Cl, pH $7.4(\mathrm{NaOH})$, and 1-5 $\mu \mathrm{M}$ tetrodotoxin (Alomone Labs). All other chemicals were purchased from Sigma.

Recording pipettes were fabricated from $1 \mathrm{~mm}$ borosilicate glass (WPI), Sylgard coated, and fire polished with tip resistances of 9-12 (postsynaptic) and 6-8 (IHC) M $\Omega$. Series resistance errors, 10-20 M $\Omega$ for IHC recordings, were compensated up to $70 \%$. Holding potentials were not corrected for LJPs. Depolarizations in trains were sometimes modified from the indicated -40 and -30 (to -45 and to $-34 \mathrm{mV}$, respectively) in order to obtain average $\mathrm{Ca}^{2+}$ currents amplitudes within the indicated values (Figs. 2-4 and 6). Experiments were done at 22$24^{\circ} \mathrm{C}$. Recordings were performed with two 200B Axopatch amplifiers and Digidata 1440 board (Molecular Devices), filtered at $10 \mathrm{kHz}$, and digitized at $50 \mathrm{kHz}$. Data acquisition started 5-10 min after the IHC whole-cell recording. A 'run-up' of $\mathrm{Ca}^{2+}$-currents was typically observed during the first few minutes of recording. After $\sim 30 \mathrm{~min}$ of recording, run-down of synaptic activity was observed and therefore only data recorded within this time window were analyzed.

Data analysis. Data were analyzed off-line using MiniAnalysis (Synaptosoft) and custom routines implemented in Igor Pro (WaveMetrics). For leak subtraction of IHC currents, IHC membrane resistance was calculated from voltage steps between -80 and $-60 \mathrm{mV} . \mathrm{Ca}^{2+}$ charge was calculated by the integral of the $\mathrm{Ca}^{2+}$ current from its onset time up to the end of the depolarizing pulse. Tail currents were excluded from the analysis because they were typically confounded by clamping artifacts. The onset time was in turn computed as the time point where the $\mathrm{Ca}^{2+}$ current trace crossed baseline (in the negative direction) after test depolarization started. Activation time constant $\left(\tau_{\text {act }}\right)$ was obtained by fitting the activation time course of the $\mathrm{Ca}^{2+}$ current from the onset time to the peak. Postsynaptic response amplitude was calculated as the sum of all EPSCs triggered by a given pulse (within a given cycle, in trains), including failures unless stated. Synaptic latency was computed from the onset of any given pulse until the onset of the EPSC (in case of first latencies, to the onset of the first EPSC activated by the stimulus). Phase plots (Figs. 1, 2,3 ) were constructed using latencies of all EPSCs occurring in each cycle of trains (or first EPSC activated, as indicated) with a given stimulation proto$\mathrm{col}$, and the characteristic phase and vector strength (synchronization index) were calculated as indicated (Goldberg and Brown, 1969).

For statistical comparison, one-tailed or two-tailed Student's $t$ test and one-way or two-way ANOVA were used. Tukey's post hoc test was used when one-way ANOVA analysis was significant, and Bonferroni's post hoc test was used in case of the two-way ANOVAs. Wilcoxon signed-rank test was used in case when normal distribution could not be assumed (ratios of response phases in 100 and $500 \mathrm{~Hz}$ stimuli; Fig. 3). Mean values are presented \pm standard errors. Recovery of synaptic responses (Fig. 5) was fitted with a single exponential equation. In case of recovery of first latencies, average $\tau$ was calculated from individual recordings in which the fitting procedure converged properly.

Simulations. The series of differential equations corresponding to a model of the IHC $\mathrm{Ca}^{2+}$ sensor (Beutner et al., 2001), with the addition of a vesicle recovery step, were solved numerically. Recovery was modeled as a single step with a rate constant that was proportional to $1 / \tau_{\text {rec }}$ as measured experimentally in Figure 5 and to the degree of emptiness of the pool (1 - sum of occupied states). Parameter values were the same as in Beutner et al., 2001: $k_{\text {on }}=27.6(\mu \mathrm{M} \mathrm{s})^{-1}, k_{\text {off }}=2150 \mathrm{~s}^{-1}, \gamma=1695$ $\mathrm{s}^{-1}$, and recovery rate $=27 \mathrm{~s}^{-1}$.

Idealized $\mathrm{Ca}^{2+}$ transients were used to drive the kinetic model (Weis et al., 1999; Beutner et al., 2001). The on- and off- time constants for the $\mathrm{Ca}^{2+}$ transients corresponding to the three levels of depolarizations were implemented following the kinetics of the corresponding $\mathrm{Ca}^{2+}$ currents $\left(\tau_{\text {on }}:-20 \mathrm{mV}, 270 \mu \mathrm{s} ;-30 \mathrm{mV}, 370 \mu \mathrm{s} ;-40 \mathrm{mV}, 430 \mu \mathrm{s} ; \tau_{\text {off }}: 100 \mu \mathrm{s}\right.$ for all pulses). This approach was considered the most parsimonious provided the lack of information on the $\mathrm{Ca}^{2+}$ dynamics with periodic stimuli as used in this study. Intracellular $\mathrm{Ca}^{2+}$ signals as measured with low affinity dyes (Frank et al., 2009) show similar time courses, albeit slightly slower, possibly due to the characteristic filtering produced by this type of $\mathrm{Ca}^{2+}$ indicators (Fig. S1 in Frank et al., 2009 showed the estimated intracellular $\mathrm{Ca}^{2+}$ waveform). The amplitude of the transients for each stimulation intensity was fit so the ratios of peak and (quasi) steady-state in the trains, and also the proportionality among train levels, were similar to the experimental results ( $45 \mu \mathrm{M}$ for the ' $-20 \mathrm{mV}$ Train,' $32 \mu \mathrm{M}$ for the ' $-30 \mathrm{mV}$ Train,' and $23 \mu \mathrm{M}$ for the ' $-40 \mathrm{mV}$ Train'). These values were kept within the range of concentrations used in previous models (Beutner et al., 2001; Wittig and Parsons, 2008). Therefore, the three different levels differ in the amplitude of the $\mathrm{Ca}^{2+}$ transients, but also in its activation kinetics, as shown for $\mathrm{Ca}^{2+}$ currents in Figure 2. For each pulse in the train, the maximal release rate was calculated together with the latency to exocytosis of the first vesicle. Multivesicular release was not considered in this simulation, and an initial pool of 200 vesicles was implemented in analogy with the number of reported vesicles on the ribbon (Nouvian et al., 2006).

\section{Results}

\section{Transmitter release during repetitive depolarization}

To examine the mechanisms underlying phase locking at the IHC ribbon synapse, we used simultaneous recordings of an IHC and a postsynaptic afferent bouton. The IHC was repeatedly depolarized (20 times) from -70 (for $2 \mathrm{~ms}$ ) to $-20 \mathrm{mV}$ for $2 \mathrm{~ms}$, constituting a $250 \mathrm{~Hz}$ stimulus rate. Typical postsynaptic responses and $\mathrm{IHC} \mathrm{Ca}^{2+}$ currents elicited by such protocols are illustrated in Figure $1 \mathrm{~A}$. As described previously (Moser and Beutner, 2000; Spassova et al., 2004; Johnson et al., 2005; Schnee et al., 2005; Goutman and Glowatzki, 2007; Li et al., 2009), synaptic depression is a prominent feature of this synapse as is evident in the average $(n=8)$ postsynaptic response (Fig. $1 B, C$ ). Synaptic depression occurred over the first $3-5$ pulses (average $\tau=2.2 \pm 0.4$ pulses), reaching a steady state $\left(14.9 \pm 0.7 \% ; n=6\right.$ paired recordings) of the initial response. $\mathrm{Ca}^{2+}$ 

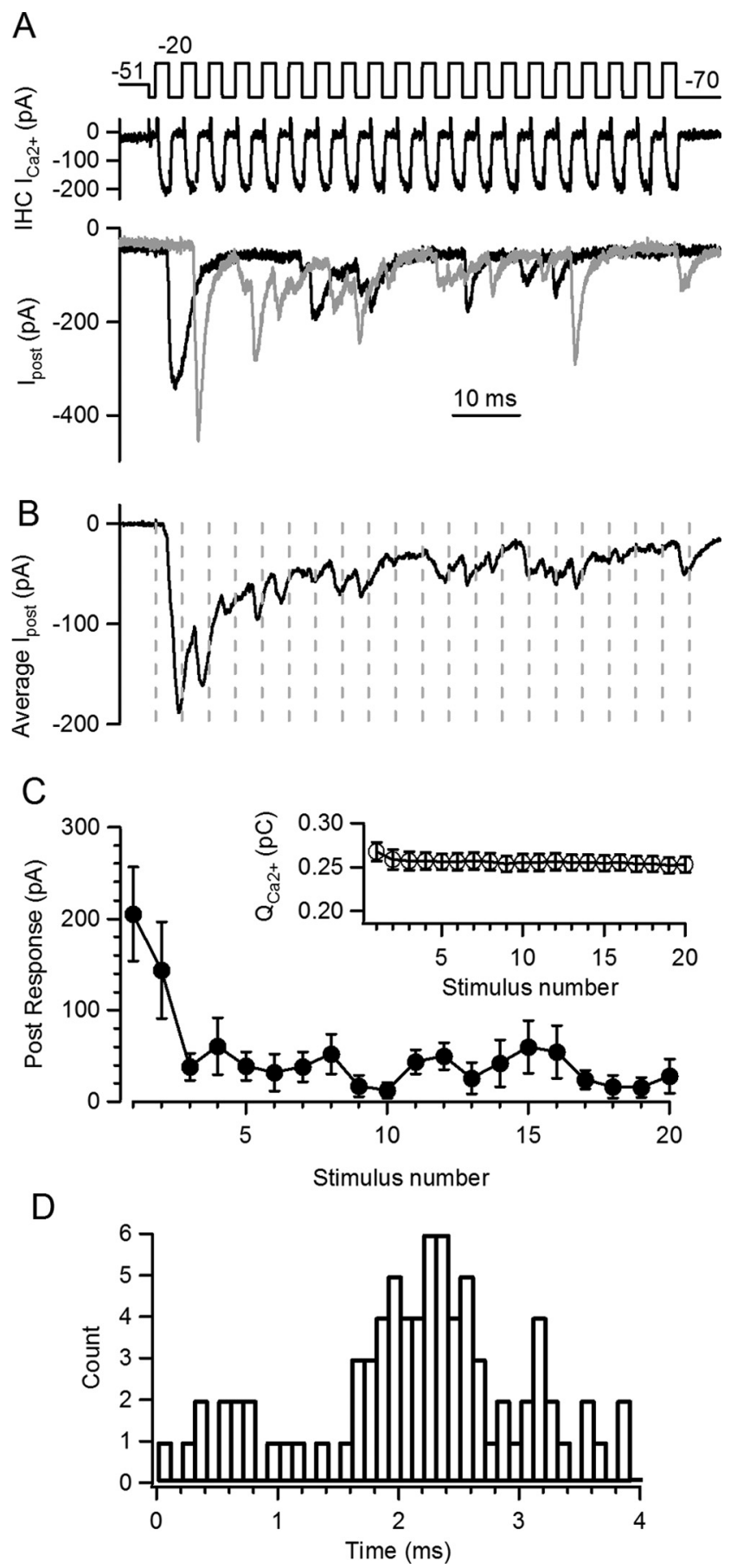

Figure 1. Periodic stimulation at the $\mathrm{IHC}$ ribbon synapse. $\boldsymbol{A}$, Train of pulses to $-20 \mathrm{mV}$ $(\mathrm{Vh}=-70 \mathrm{mV}, 2 \mathrm{~ms}+2 \mathrm{~ms}$, i.e., $250 \mathrm{~Hz}$ ) following a predepolarization to $-51 \mathrm{mV}$. Top panel: stimulation protocol, middle panel: $\mathrm{IHCC}{ }^{2+}$ currents, bottom panels: two repetitions of the postsynaptic response. $\boldsymbol{B}$, Average trace of $n=8$ postsynaptic responses. Dashed lines indicate cycles' limit, where local peaks of the postsynaptic response can be observed. C, Average amplitude of postsynaptic responses at each pulse in the train. Note fast synaptic depression. Inset, $\mathrm{Ca}^{2+}$ charge produced by each pulse in the train at the IHC. Slight inactivation was observed during the train. D, Phase (or latency) plot for all EPSCS occurring during the train, regardless of their amplitudes or shapes. The histogram was constructed with latencies of all EPSC activated in each cycle, relative to the beginning of that cycle.

currents activated during trains were also analyzed. The $\mathrm{Ca}^{2+}$ charge $\left(\mathrm{Q}_{\mathrm{Ca}^{2+}}\right)$, as the integral of the current elicited during the $2 \mathrm{~ms}$ pulses, was measured for each depolarization in the train (Fig. $1 C$, inset). A reduction was observed by the end of the train, $7 \pm 2 \%(0.22 \pm$
$0.03 \mathrm{pC}$ for first stimulus), probably due to $\mathrm{Ca}^{2+}$-dependent inactivation of voltage-dependent $\mathrm{Ca}^{2+}$ channels (Grant and Fuchs, 2008), suggesting that part of the synaptic depression could be due to a reduced influx of $\mathrm{Ca}^{2+}$ to the cell.

EPSCs activated during trains, as shown in Figure $1 \mathrm{~A}$, regardless of their amplitudes or shape, were used to build a phase plot (Fig. 1D). This histogram represents the latencies of all EPSCs activated in each cycle, relative to the onset of that one cycle. The peak in this distribution indicates the time point within each cycle with the highest probability of EPSC occurrence. As the referential point to measure latency changes from cycle to cycle within the periodic waveform, latency in transmitter release should also be considered a phase of a periodic response. We will refer to this observation with both terms (latency and phase). The average phase (or latency) was calculated as suggested by Goldberg and Brown (1969) for the one recording shown in Figure $1 D$, obtaining a value of $2.1 \mathrm{~ms}$, and for $n=6 \mathrm{IHC}$-afferent pairs, an average of $2.53 \pm 0.07 \mathrm{~ms}$ (at $250 \mathrm{~Hz}, 5-12$ repetitions each). For clarity, we will use the time scale to measure the average phase (as indicated above), although the corresponding value in radians would be $3.9 \pm 0.8$ and $223^{\circ} \pm 5^{\circ}$ in degrees. The average phase parameter can also be constructed with solely latencies to the first EPSC in each cycle, but the resulting value was very similar to what described above $(2.45 \pm 0.07 \mathrm{~ms}, n=6, t$ test $p=0.12)$.

Another important consideration is the level of synchronization of the events around the mean phase. This is quantified with the parameter $r$ (vector strength or synchronization index) that provides a value of 0 in case of no phase-locking and 1 when events are perfectly synchronized (Goldberg and Brown, 1969). We obtained an average $r$ of $0.38 \pm 0.04$ for $n=6$ recordings that is significantly different from a theoretically non-phase-locked response ( $t$ test, one sample, $p<0.0001$ ) (when computed with first EPSCs in each cycle, $r=0.37 \pm 0.03$ )

Phase-locked responses were also obtained with stimulating frequencies of 100 and $500 \mathrm{~Hz}$ (see below, Phase constancy in trains with different levels of depolarizations and frequencies).

\section{Phase constancy in trains with different levels of depolarizations and frequencies}

Interestingly, auditory nerve fibers conserve a preferred phase regardless of the intensity of the stimulus (Kiang et al., 1965; Rose et al., 1967). Presynaptic hair cells were subjected to depolarizing trains at different voltage levels $(-40,-30$, and $-20 \mathrm{mV}$ ) to mimic a range of sound intensities. These values span the range of potentials at which this synapse would operate in physiological conditions (Brandt et al., 2003; Johnson et al., 2005; Schnee et al., 2005; Keen and Hudspeth, 2006; Goutman and Glowatzki, 2007). Individual (Fig. 2 A) and average (Fig. 2 B2) postsynaptic responses during these three levels of hair cell depolarization are shown. In agreement with previous results, trains to $-20 \mathrm{mV}$ produced the largest average responses, followed by trains to $-30 \mathrm{mV}$. As for $-20 \mathrm{mV}$ trains, the $-30 \mathrm{mV}$ ones showed synaptic depression over the first few pulses, whereas short-term facilitation occurred at the $-40 \mathrm{mV}$ trains presumably due to lower release probability during this stimulus. The average maximal response was $205 \pm 51 \mathrm{pA}$ for the $-20 \mathrm{mV}$ train, $139 \pm 40 \mathrm{pA}$ for the -30 $\mathrm{mV}$ train, and $61 \pm 28 \mathrm{pA}$ for the $-40 \mathrm{mV}$ train for recordings shown in Figure 2, and $140 \pm 14 \mathrm{pA}, 87 \pm 15 \mathrm{pA}$, and $34 \pm 7$ pA for average of $n=6$ cell pairs ( $6-12$ repetitions each).

The last five pulses in each train were used to compute the (quasi-)steady-state level of the ensemble response at each depolarization level, with average values of $-22 \pm 3 \mathrm{pA}$ for the train at 
A
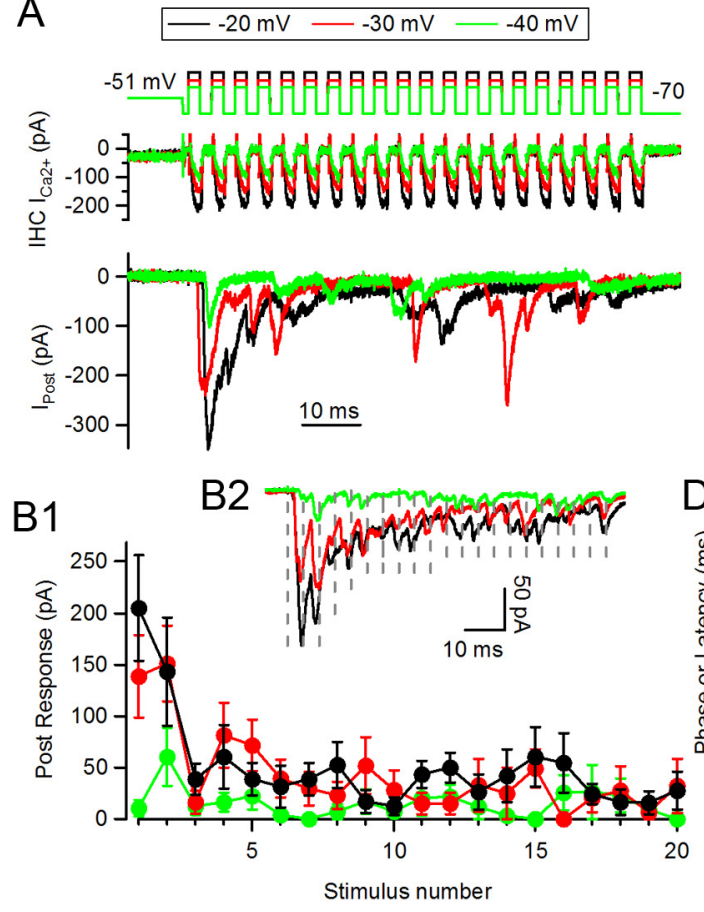

C

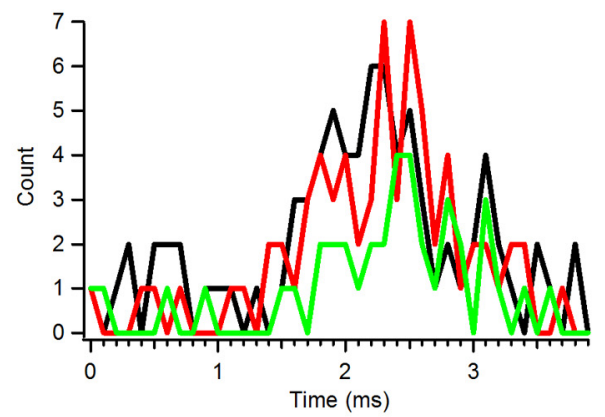

$\mathrm{E}$

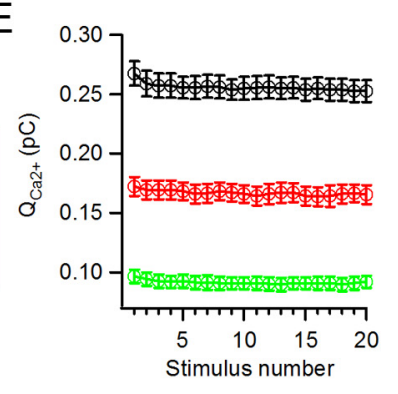

Figure 2. Responses to trains of pulses at different potentials are phase locked. $A$, Representative traces of synaptic responses at three different depolarization values: $-20 \mathrm{mV}(\mathrm{black}),-30 \mathrm{mV}$ (red), and $-40 \mathrm{mV}$ (green). Same panel distribution as Figure $1 A . B 1$, Average peak postsynaptic responses per pulse for each level of stimulation. $\boldsymbol{B 2}$, Average traces $(n=8-12$ repetitions) of synaptic responses for each train type (dashed lines indicate cycles). C, Phase (or latency) plot for EPSCs activated during any given cycle of the train (as indicated in Fig. 1D). D, Average preferred phase calculated for $n=5$ cell pairs. $E$, $I H C Q_{\mathrm{Ca}^{2+}}$ at each pulse in the train for the three different levels.

$-20 \mathrm{mV}, 19 \pm 4 \mathrm{pA}$ for the train at $-30 \mathrm{mV}$, and $9 \pm 3 \mathrm{pA}$ for the train at $-40 \mathrm{mV}$ ( $n=6$ cell pairs, $6-12$ repetitions each, ANOVA $p=0.01)$. It is important to note that these values correspond to average responses per pulse, including release failures.

We also computed the average size of individual EPSCs for the three different depolarization levels (events in 'successful' cycles of the second half of each train). In the $-20 \mathrm{mV}$ trains the average EPSC was $82 \pm 9 \mathrm{pA}$ ( $n=5$ cells, $16-39$ EPSCs per cell), $96 \pm 10 \mathrm{pA}$ (13-23 EPSCs) for the $-30 \mathrm{mV}$ trains, and for the $-40 \mathrm{mV}$ trains $90 \pm 13$ pA (3-18 EPSCs) (not shown). Thus, individual EPSCs were multivesicular, and the average size was constant across train intensities (ANOVA, $p=0.14$ ), in agreement with previous results (Glowatzki and Fuchs, 2002; Goutman and Glowatzki, 2007).

The phase of synaptic responses (or latency) was measured within cycles of trains to different presynaptic membrane potentials. Phase plots are shown for one cell pair in Figure $2 C$, where it can be seen that the average phase was found at $t=2.30 \mathrm{~ms}, 2.38$ $\mathrm{ms}$, and $2.53 \mathrm{~ms}$ for the $-20,-30$ and $-40 \mathrm{mV}$ trains, respectively. This same parameter was calculated for $n=5$ recordings (Fig. 2D), obtaining average phases of $2.53 \pm 0.07,2.44 \pm 0.06$, and $2.62 \pm 0.09 \mathrm{~ms}$ for the same three depolarization levels and are not significantly different from each other (ANOVA, $p=$ 0.23 ). The same parameters were computed solely with first latencies instead of all events in each cycle, but no significant differences were observed in this case either (data not shown).

These three distinct levels of stimulation expectedly produced presynaptic $\mathrm{Ca}^{2+}$ currents of different size and kinetics. Figure $2 E$ shows $\mathrm{Q}_{\mathrm{Ca}^{2+}}{ }^{2+}$ generated in each pulse by the three stimulation protocols. The $-20 \mathrm{mV}$ train produced a peak $\mathrm{Q}_{\mathrm{Ca}^{2+}}$ at the first stimulus of $0.22 \pm 0.03 \mathrm{pC}$ as shown in Figure $1 C$ (inset), whereas peak $\mathrm{Q}_{\mathrm{Ca}^{2+}}$ for the $-30 \mathrm{mV}$ train was $0.12 \pm 0.01 \mathrm{pC}$, and $0.06 \pm$ $0.01 \mathrm{pC}$ for the $-40 \mathrm{mV}$ train (ANOVA, $p<0.0001$ ). Activation kinetics (single exponential) were strongly voltage dependent and averaged $\tau_{\text {act }}=273 \pm 28 \mu$ s for the $-20 \mathrm{mV}, 366 \pm 42 \mu \mathrm{s}$ for $-30 \mathrm{mV}$, and $429 \pm 66 \mu \mathrm{s}$ for $-40 \mathrm{mV}$ (not shown, ANOVA, $p<$ $0.0001)$.

Periodic stimuli at frequencies different from $250 \mathrm{~Hz}$ with maximal depolarizations of -20 and $-30 \mathrm{mV}$ were also applied. Both trains of square pulses and sinusoidal stimulation at $100 \mathrm{~Hz}$ produced synaptic depression with maximal responses of $404 \pm$ $120 \mathrm{pA}$ and $170 \pm 42 \mathrm{pA}$ at -20 and $-30 \mathrm{mV}$, respectively $(n=$ 4 cell pairs each, 5-27 repetitions each, $t$ test, $p=0.08$ ) and steady-state values of $81 \pm 23 \mathrm{pA}$ and $46 \pm 9 \mathrm{pA}$ for the same potentials ( $n=4$, $t$ test, $p=0.09$ ) (Fig. $3 A, B)$. The maximal and steady-state responses of the $-20 \mathrm{mV}$ trains at $100 \mathrm{~Hz}$ are larger than the corresponding responses at $250 \mathrm{~Hz}$ ( $t$ test, $p=0.047$ ), which is consistent with longer depolarizations in each cycle of the train. Synaptic responses at these low-frequency trains were also phase locked, and the average phase was not different when comparing the two evaluated levels. As different stimulation protocols (train of square pulses or sinusoidal waveform) were used in different recordings, and provided that the average phase could change depending on the shape of the stimulus, both absolute phase values and also ratios between $-20 \mathrm{mV}$ and $-30 \mathrm{mV}$ stimuli in each recording were calculated. For the recordings shown in Figure $3 A-C$, the average phase was 6.6 at $-20 \mathrm{mV}$ and $6.9 \mathrm{~ms}$ at $-30 \mathrm{mV}$ trains, and for $n=4$ cell pairs the averages were $6.3 \pm 0.7 \mathrm{~ms}$ at $-20 \mathrm{mV}$ and $6.7 \pm 0.5 \mathrm{~ms}$ at $-30 \mathrm{mV}(n=4, t$ test $p=0.18$ ) (Fig. 3C). Calculating ratios between $-30 \mathrm{mV}$ and -20 $\mathrm{mV}$ phases, the average was $1.07 \pm 0.05$ (Wilcoxon signed-rank test, $p>0.05$ ).

Increasing the frequency of stimulation produced a higher rate of failures per stimulus, consistent with shorter on-periods. Maximal responses of trains of square pulses or alternatively sinusoidal stimulation at $500 \mathrm{~Hz}$ with depolarizations to $-20 \mathrm{mV}$ were $113 \pm 25 \mathrm{pA}$, and at $-30 \mathrm{mV}, 83 \pm 27 \mathrm{pA}(n=4$ cell pairs 
A
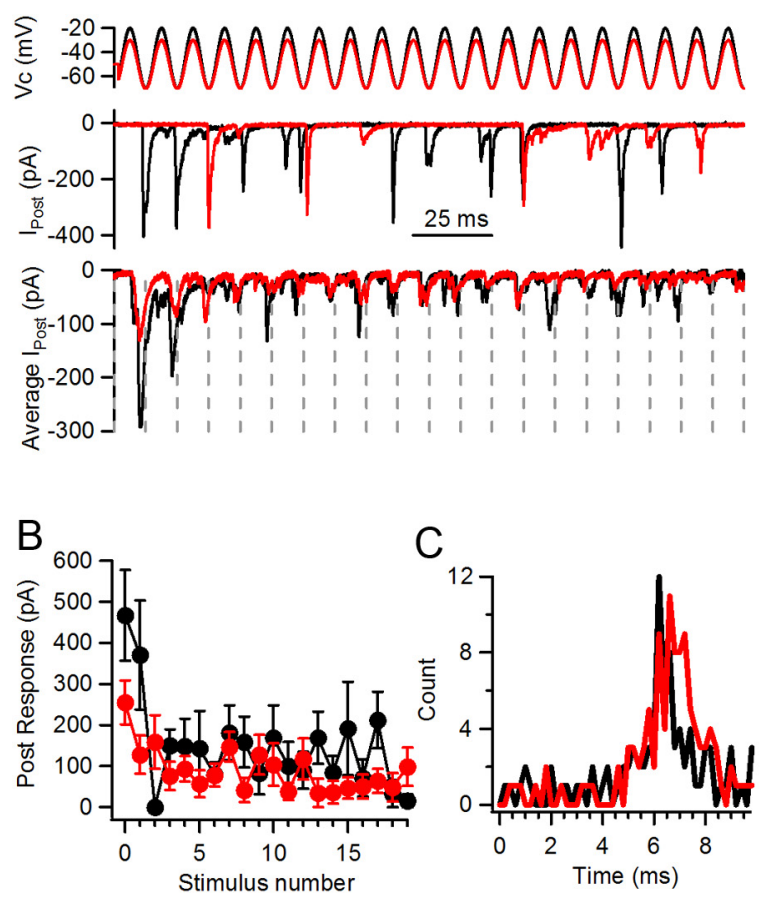

C

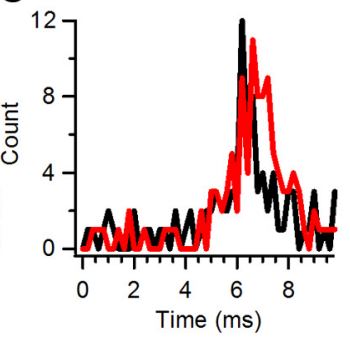

$\mathrm{D}$

$500 \mathrm{~Hz}$
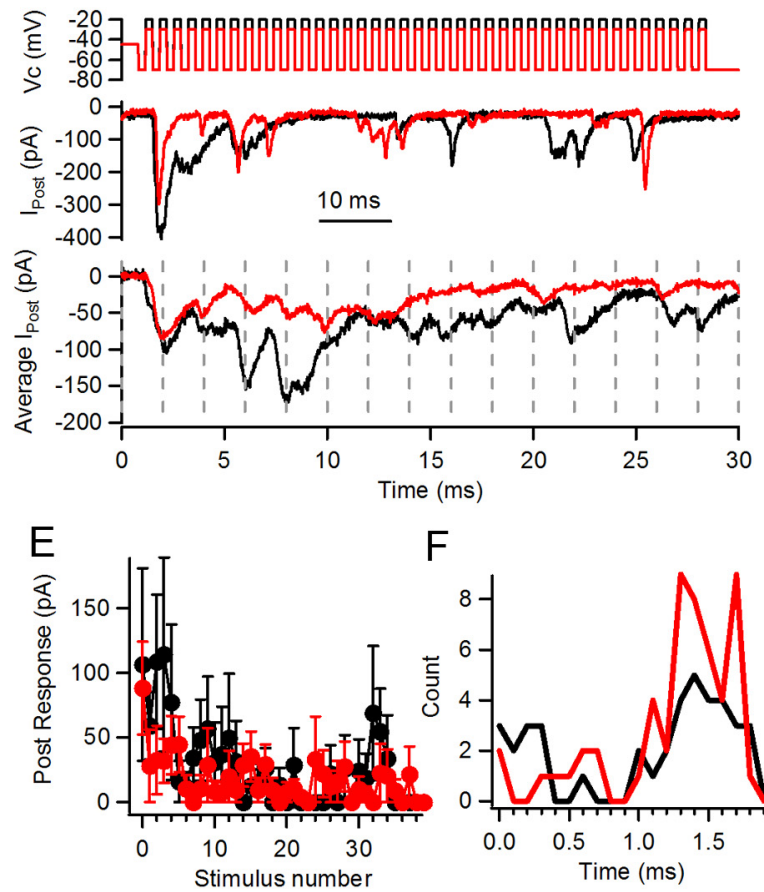

$\mathrm{F}$

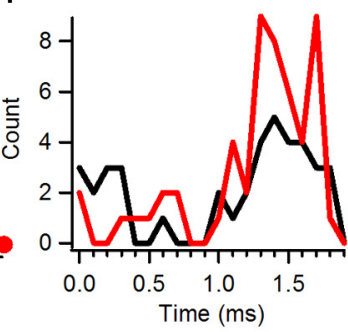

Figure 3. Phase locking at stimulation frequencies of $100 \mathrm{and} 500 \mathrm{~Hz}$. A, Representative postsynaptic responses to sinusoidal stimulation ( $20 \mathrm{cycles}$ ) of $100 \mathrm{~Hz}$ at $-20 \mathrm{mV}$ (black) and $-30 \mathrm{mV}$ (red). Top panel, Stimulation protocol; middle panel, individual postsynaptic responses to these two levels; bottom, average traces of $n=6(-20 \mathrm{mV})$ and $12(-30 \mathrm{mV})$ responses. Individual cycles are separated by dashed lines. Note local peaks within each cycle for both train levels. $\boldsymbol{B}$, Average amplitude of postsynaptic responses per pulse at both depolarization levels. $\boldsymbol{C}$, Phase (or latency) plot for recording shown in $\boldsymbol{A}$ and $\boldsymbol{B}$. D. Representative responses to $500 \mathrm{~Hz}$ stimulation at $-20 \mathrm{mV}$ and $-30 \mathrm{mV}$ ( 40 pulses). Same panel distribution as in $\boldsymbol{A}$, but a detail of the first 15 cycles in the train is shown on the bottom panel (dashed lines indicate cycles). $\boldsymbol{E}$, Average postsynaptic response per pulse. Smaller average responses were observed per pulse. $\boldsymbol{F}$, Phase (latency) plot for the recording shown in $\boldsymbol{D}$ and $\boldsymbol{E}$.

each, $t$ test, $p=0.107$ ) (Fig. 3D). Phase locking occurred also at this frequency, with average phases (or latencies) for the recording shown in Figure $3 D$ of $1.65 \mathrm{~ms}$ at $-20 \mathrm{mV}$ and $1.49 \mathrm{~ms}$ at -30 $\mathrm{mV}$ trains, and mean ratios for these two potentials of $1.01 \pm 0.07$ $(n=4$ cell pairs, Wilcoxon signed-rank test $p>0.05)($ Fig. $3 F)$.

Ratios for average phases at $250 \mathrm{~Hz}$ trains were computed as well, rendering close to 1 values for both $-30 /-20 \mathrm{mV}$ trains and for $-40 /-20 \mathrm{mV}$ trains $(0.98 \pm 0.04$ and $1.03 \pm 0.03$, respectively).

In summary, these results show that transmitter release from the IHC ribbon synapse is phase locked to cyclic stimuli of different frequencies, and that the phase is conserved independently of stimulus strength (hair cell depolarization). IHC voltage-gated $\mathrm{Ca}^{2+}$ channels activate more extensively and faster as the membrane is progressively depolarized (Fig. $2 \mathrm{C}$ and (Moser and Beutner, 2000; Marcotti et al., 2003). This leads to the following question: why does the timing of repetitive EPSCs, which is strongly dependent on $\left[\mathrm{Ca}^{2+}\right]_{\mathrm{i}}$, remain unchanged with hair cell depolarization (Figs. 2E,3C,F).

\section{Timing of single postsynaptic responses is voltage $\left(\mathrm{Ca}^{2+}\right)$ dependent}

To probe the kinetics of transmitter release at the IHC ribbon synapse, single 10-ms-long depolarizations of varied amplitude were applied during paired recordings. Presynaptic steps to -20 $\mathrm{mV}$ produced EPSCs with an average amplitude of $462 \pm 105 \mathrm{pA}$ ( $n=4$ cell pairs, $3-5$ repetitions each, Fig. $4 A 1, B)$. Smaller responses were obtained for smaller depolarizations, $314 \pm 73 \mathrm{pA}$ for presynaptic steps to $-30 \mathrm{mV}$, and $201 \pm 67 \mathrm{pA}$ for steps to $-40 \mathrm{mV}(n=4$, Fig. $4 B)$. Earlier work showed that short-term plasticity affects the size and timing of the synaptic response (Cho et al., 2011; Goutman and Glowatzki, 2011; Schnee et al., 2011). No significant changes in amplitude were obtained when saturating pulses to $-20 \mathrm{mV}$ were preceded by a predepolarization $(491 \pm 110 \mathrm{pA}, n=4,2$-way ANOVA, $p>0.05$, Fig. 4A2) as described (Goutman and Glowatzki, 2011), but strong facilitation was observed for submaximal pulses; conditioning depolarizations facilitated responses at $-40 \mathrm{mV}$ by $98 \pm 44 \%(315 \pm 56$ $\mathrm{pA}, n=4$ cell pairs, two-way ANOVA $p<0.01)$ and at $-30 \mathrm{mV}$ by $66 \pm 19 \%$ (486 \pm 81 pA, two-way ANOVA, $p<0.001)$.

Figure $4 C$ shows synaptic latencies to the first EPSC after the pulse as a function of the command potential. As described for other synapses, there is a close relation between $\mathrm{Ca}^{2+}$ current size and postsynaptic response timing, as higher $\mathrm{Ca}^{2+}$ influx provokes larger and faster release (Llinás et al., 1981; Felmy et al., 2003). The IHC ribbon synapse behaves similarly. Synaptic latency for presynaptic pulses to $-40 \mathrm{mV}$ (without a conditioning predepolarization) was $7.07 \pm 1.18 \mathrm{~ms}(n=4$ cell pairs, $3-5$ repetitions) and $3.34 \pm 0.45 \mathrm{~ms}$ at $-20 \mathrm{mV}(n=4$ cell pairs, two-way ANOVA, $p<0.05$ ) (Fig. $4 C$ ). Interestingly, when the synapse was facilitated (after predepolarization), latency to all three potentials was shorter $(-40 \mathrm{mV}, 3.38 \pm 0.53 \mathrm{~ms} ;-30 \mathrm{mV}$, $2.05 \pm 0.39 \mathrm{~ms} ;-20 \mathrm{mV}, 1.56 \pm 0.30 \mathrm{~ms} ; p<0.001)$. It is important to note that a constant reduction of $\sim 50 \%$ was obtained across physiological potentials due to facilitation (49\% for $-40 \mathrm{mV}, 50 \%$ for $-30 \mathrm{mV}$, and $48 \%$ for $-20 \mathrm{mV}$ ), but differences persisted when comparing between potentials (two-way ANOVA, $p=0.018$ ). Jitter in synaptic latency underwent a reduction caused by predepolarizations (e.g., $-40 \mathrm{mV} \mathrm{SD}$ of latency: $2.18 \pm 0.42 \mathrm{~ms}$ to $1.24 \pm 0.23 \mathrm{~ms}$, two-way ANOVA, $p<$ 


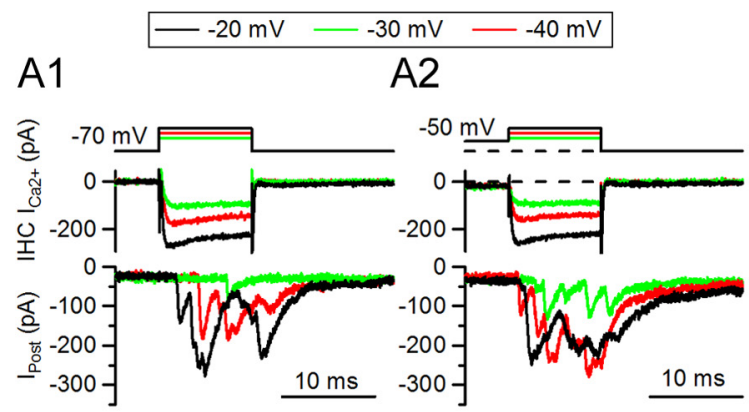

E1

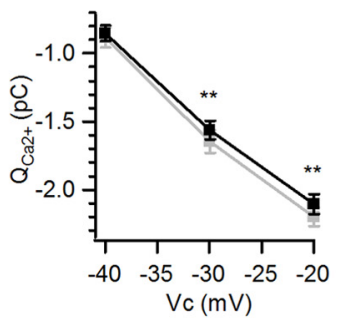

E2

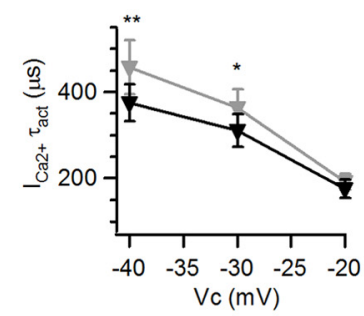

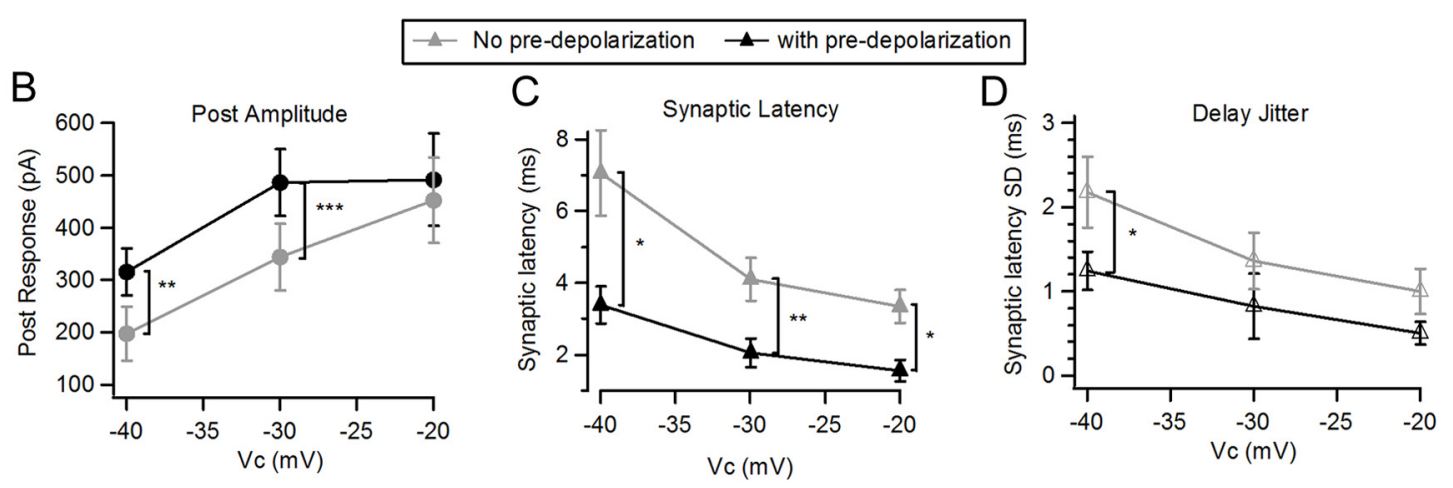

Figure 4. Timing of synaptic responses in single pulses at different potentials. $\boldsymbol{A} 1$, Synaptic responses at three different potentials, -40 (red), -30 (green), and -20 (black) $\mathrm{mV}$, with no predepolarization. Presynaptic voltage protocol is on top, $\mathrm{IHC} \mathrm{Ca}^{2+}$ currents are in the middle, and postsynaptic currents are in the bottom panels. $\boldsymbol{A 2}$, Same as $\boldsymbol{A} \mathbf{1}$ but using predepolarization to $-50 \mathrm{mV}$ for $50 \mathrm{~ms}$. B, Average amplitude of postsynaptic responses as a function of depolarizing potential (with or without predepolarization). $\boldsymbol{C}$, First synaptic latency for responses elicited with

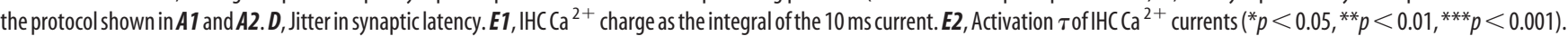

0.05) (Fig. 4D). These results indicate that when the synapse is facilitated by a predepolarization, transmitter release occurs faster and with greater precision.

$\mathrm{Ca}^{2+}$ currents also showed higher amplitude and faster activation with pulses to more depolarized potentials (Fig. 4E1,E2). Predepolarizations also produced changes in these parameters, but only at -20 and $-30 \mathrm{mV}$ steps; $\mathrm{Ca}^{2+}$ influx decreased from $2.20 \pm 0.07 \mathrm{pC}$ to $2.10 \pm 0.07 \mathrm{pC}$ at $-20 \mathrm{mV}$ and from $1.65 \pm$ $0.08 \mathrm{pC}$ to $1.56 \pm 0.07 \mathrm{pC}$ at $-30 \mathrm{mV}$ steps (two-way ANOVA, $p<0.01)$. Presteps also produced faster activation of $\mathrm{Ca}^{2+}$ currents (e.g., at $-40 \mathrm{mV}$ steps $\tau_{\text {act }}: 0.46 \pm 0.06 \mathrm{~ms}$ to $0.38 \pm 0.04$ ms, two-way ANOVA, $p=0.0004)$.

It can be argued that the duration of pulses in Figure 4 is different from the corresponding ones at the stimulating frequencies used in Figures 1-3 (2 ms for $250 \mathrm{~Hz}, 5 \mathrm{~ms}$ for $100 \mathrm{~Hz}$, and $1 \mathrm{~ms}$ for $500 \mathrm{~Hz}$ ) and that different results may arise. The duration of the pulse in Figure $4(10 \mathrm{~ms})$ was selected to maximize the release probability and so obtain a large number of events to analyze. One possibility is that tail currents of shorter pulses, or during trains, could set synaptic latency by the transient influx of $\mathrm{Ca}^{2+}$ that they produce. This was explicitly tested by performing similar experiments as shown in Figure 4, but with pulses of $2 \mathrm{~ms}$. The two more positive presynaptic levels were exclusively tested, as many more failures are observed with the shorter pulses at less depolarized potentials. Similarly to the differences shown for the $10 \mathrm{~ms}$ pulses (where tail currents did not participate in triggering release), synaptic latency was shorter for the $-20 \mathrm{mV}$ pulses $(2.39 \pm 0.17 \mathrm{~ms})$ than for the $-30 \mathrm{mV}$ ones $(3.07 \pm 0.20 \mathrm{~ms})$ ( $n=5, p=0.022, t$ test $)$.

\section{Efficient recovery of the synaptic response is required for phase maintenance}

Experimental and theoretical evidence suggests that precise timing at the IHC ribbon synapse depends on a large, readily releas- able pool of vesicles (Wittig and Parsons, 2008; Trapani et al., 2009). Thus, phase locking during repetitive hair cell depolarization would also require efficient vesicular resupply. A $10 \mathrm{~ms}$ depolarization from -80 to $-20 \mathrm{mV}$ was sufficient to reach the peak of the ensemble postsynaptic response, consistent with deconvolution analysis indicating that the first component of release had a time constant of $2.1 \mathrm{~ms}$ (Goutman and Glowatzki, 2007). This stimulus was used to partially deplete the pool of synaptic vesicles and was then repeated at intervals out to $1 \mathrm{~s} \mathrm{(Fig.}$ $5 A)$. Due to the stochastic nature of release at the IHC ribbon synapse, recovery after every interval was tested 3-8 times, and the resulting EPSC was averaged (including failures). Recovery occurred quickly, with a monoexponential time course $\left(\tau_{\text {rec }}=\right.$ $37 \pm 9 \mathrm{~ms} ; n=5$ cell pairs, both with or without cyclothiazide, Fig. $5 B$ ). The integral of the $\mathrm{Ca}^{2+}$ current generated during each pulse showed no significant change (ANOVA, $p=0.11$, not shown).

It is of interest to note that the synaptic latency also correlated with the degree of recovery. Figure $5 C$ shows average synaptic latencies for responses at different intervals after the depleting stimulus (average latency for $\mathrm{S} 1$ indicated by dashed line). As the response recovered, latency decreased (ANOVA, $p=0.03$ ), following a time course similar to that indicated previously $\left(\tau_{\text {rec, }}\right.$ latency $=54 \pm 12 \mathrm{~ms}$ ), consistent with the proposed dependence of release timing on pool size (Wittig and Parsons, 2008).

\section{Interplay between depression and stimulus strength}

The foregoing analysis demonstrates that vesicle pool depletion must occur during the standard stimulus train (20 stimuli at 250 $\mathrm{Hz}$; total duration, $80 \mathrm{~ms}$ ). However, the extent of this depression must depend on the initial probability of release, varying with presynaptic depolarization. These two effects will combine to provide a level of depression at the end of each train, which was tested explicitly by applying an additional $10 \mathrm{~ms}$ step to $-20 \mathrm{mV}$. 
A

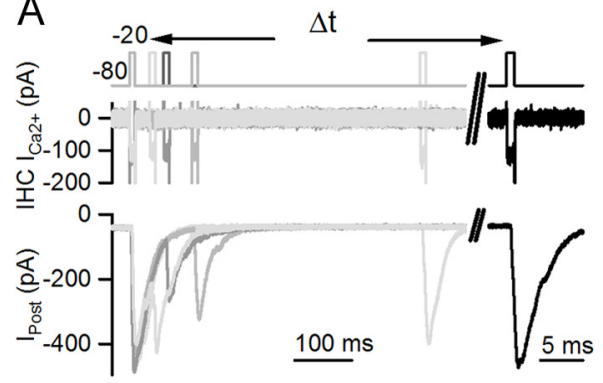

B

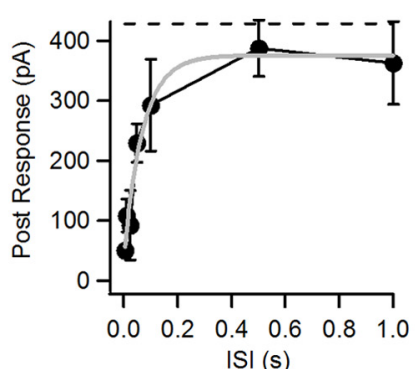

C

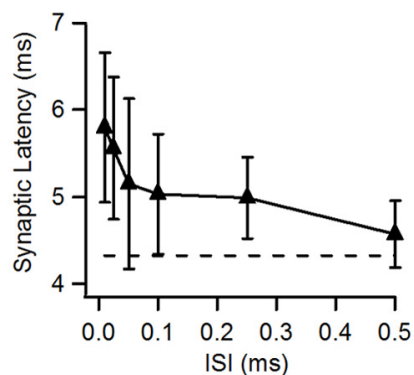

Figure 5. Fast synaptic recovery after partially depleting stimuli. $\boldsymbol{A}$, An initial $10 \mathrm{~ms}-$ pulse was applied to elicit a partial depletion of the vesicle pool. Recovery after different intervals was assayed with a second $10 \mathrm{~ms}$ - pulse. Representative traces are shown; voltage protocol at the $\mathrm{IHC}$ is in the top panel, $\mathrm{HCCa}^{2+}$ current is in the middle, and postsynaptic response in the bottom. $B$, Average postsynaptic response as a function of recovery interval. Also, average response to first stimulus is included as dashed line. Gray line represents fit with exponential function $\boldsymbol{C}$, Synaptic latency of second depolarization as a function of interval. Average latency of responses to first depolarization is indicated as horizontal dashed line.

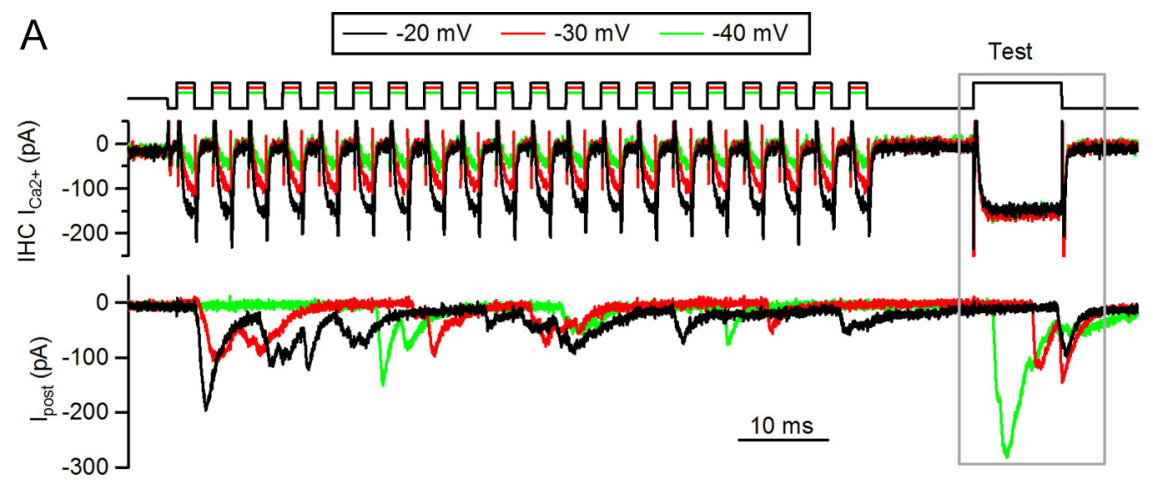

E
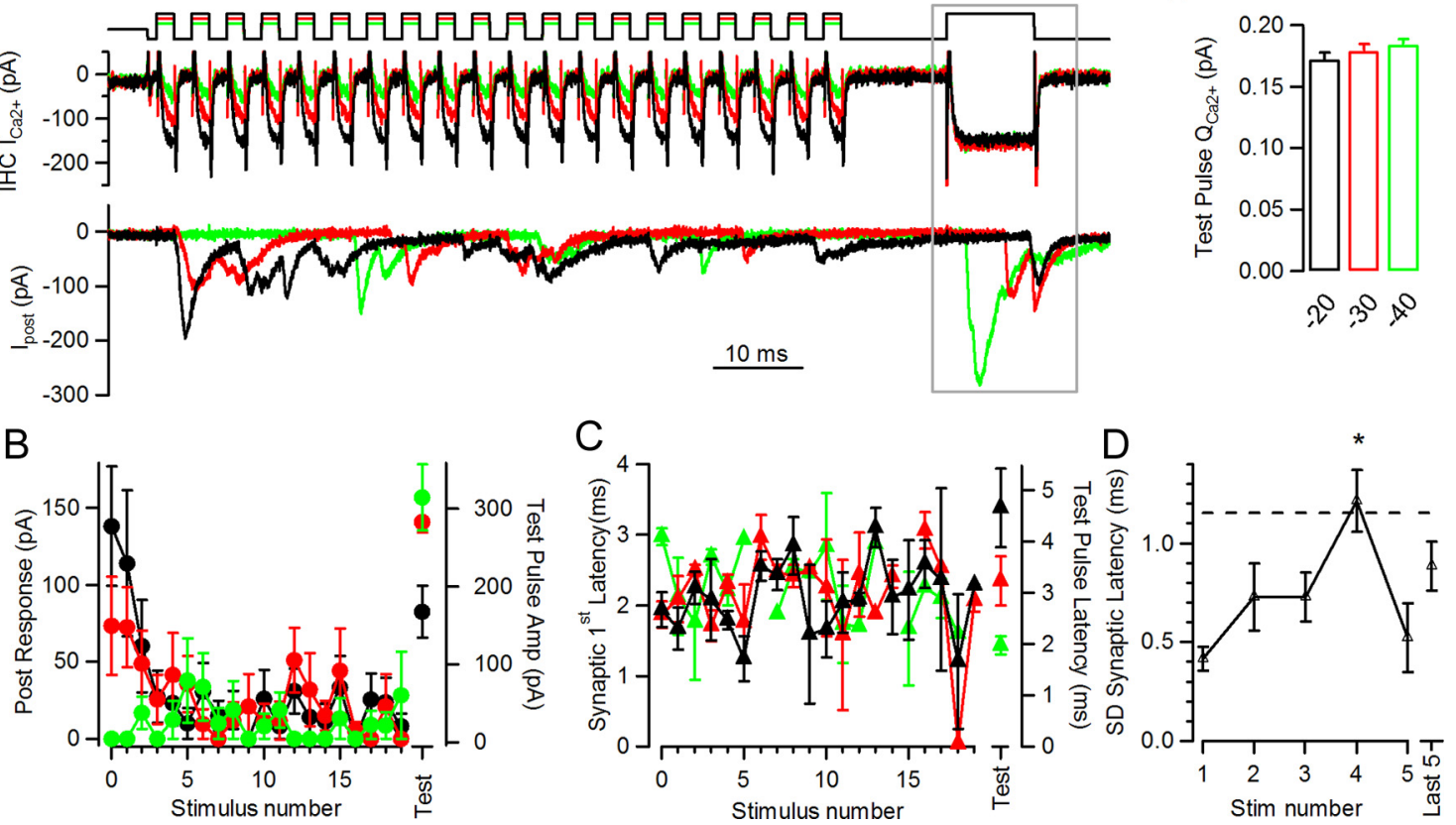

Figure 6. Testing vesicle pool state after trains of $250 \mathrm{~Hz}$ at different levels. $A$, Representative traces of responses to stimulation protocols at three different levels, followed by test pulse $(10 \mathrm{~ms}$ depolarization to $-20 \mathrm{mV}$, after $10 \mathrm{~ms}$ interval at the end of the train). $\boldsymbol{B}$, Average postsynaptic response versus stimulus number (left axis), and test pulse amplitude (right axis). $\boldsymbol{C}$, Average synaptic latency after every pulse in each train (left axis), and also to the test pulse (right axis). $\boldsymbol{D}$, Jitter in latency (measured as standard deviation of the mean) for the first five pulses in the $-20 \mathrm{mV}$ trains and the events occurring in the ensemble's last five depolarizations. Dashed line indicates theoretical jitter for events occurring with equal probability at any point in time over the entire cycle $\left({ }^{*} p<\right.$ 0.05). $E_{,} \mathrm{Ca}^{2+}$ charge at test pulse.

This 'test pulse' was designed to release any remaining vesicles and, therefore, to reveal the degree of depression occurring during stimulus trains to different presynaptic voltages (Fig. 6).

Average postsynaptic responses during the 20 stimuli trains, before the test pulse, were similar to those shown in Figure 2. The test pulse at the end of a train to $-20 \mathrm{mV}$ elicited a response with an average amplitude of $227 \pm 29 \mathrm{pA}(n=4$ cell pairs, $3-10$ repetitions each) (Fig. $6 A, B$ ). The average response at the end of the $-40 \mathrm{mV}$ train was significantly larger, $413 \pm 35 \mathrm{pA}$ (ANOVA, $p=0.0005)$, and an intermediate result was obtained in the case of the $-30 \mathrm{mV}$ train $(335 \pm 20 \mathrm{pA}$, ANOVA $p<0.005)$. Synaptic latency of the test EPSC was longer after more intense trains (Fig. $6 C)(-20 \mathrm{mV}$, latency $5.0 \pm 0.7 \mathrm{~ms}$ in average of $n=4$ cell pairs $)$ and shorter after less demanding trains $(-40 \mathrm{mV}$ train, $2.1 \pm 0.1$ ms, ANOVA, $p=0.0011$ ). This result contrasts with the overall constant synaptic phases (or latencies) across trains of different intensities (Figs. 2C,E). $\mathrm{Ca}^{2+}$ currents at the test pulse (Fig. 6E) were not significantly different among the three different protocols $\left(\mathrm{Q}_{\mathrm{Ca}^{2+}}\right.$ for the $-20 \mathrm{mV}$ train was $0.18 \pm 0.02 \mathrm{pC}$, for the -30 $\mathrm{mV}$ train it was $0.18 \pm 0.02 \mathrm{pC}$, and for the $-40 \mathrm{mV}$ it was $0.19 \pm$ $0.03 \mathrm{pC}$, ANOVA $p=0.6)$. Jitter in synaptic latency was also computed, but due to the scarce number of events, it was done only for the $-20 \mathrm{mV}$ trains at each of the first five depolarizations and the ensemble of the last five pulses (Fig. 6D). The standard deviation (jitter) for $n=4$ recordings was fairly constant throughout the train, except for stimulus number 4 (1.22 \pm 0.16 ms, ANOVA, $p<0.05$ ), which was over the critical value of $\sim 1.2$ $\mathrm{ms}$, corresponding to a random temporal distribution of events within a cycle (Fig. 6D, dashed line; see Materials and Methods). This observation resembles the unchanged spike-timing precision observed after adaptation in the auditory nerve (Avissar et al., 2007). 

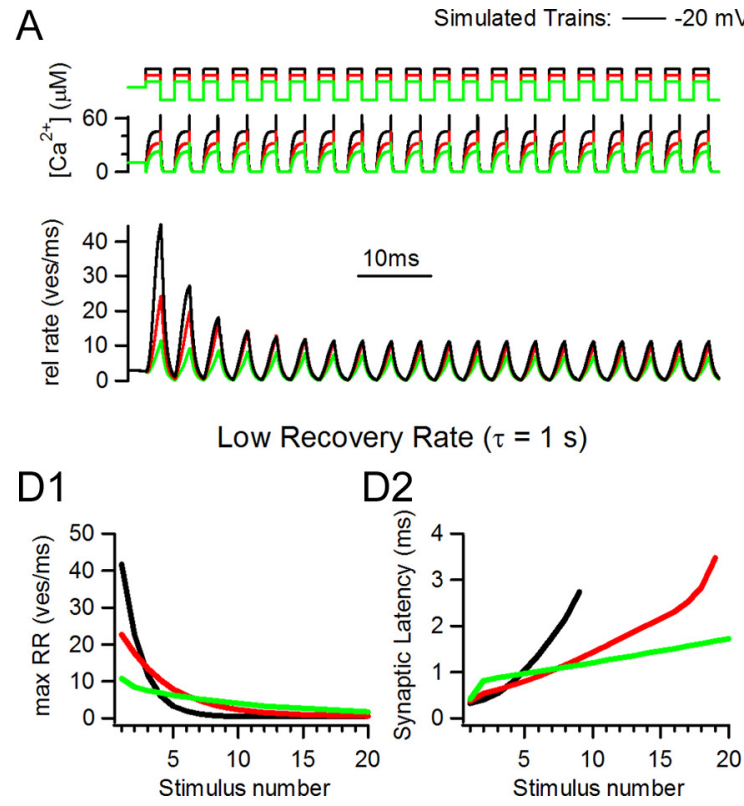
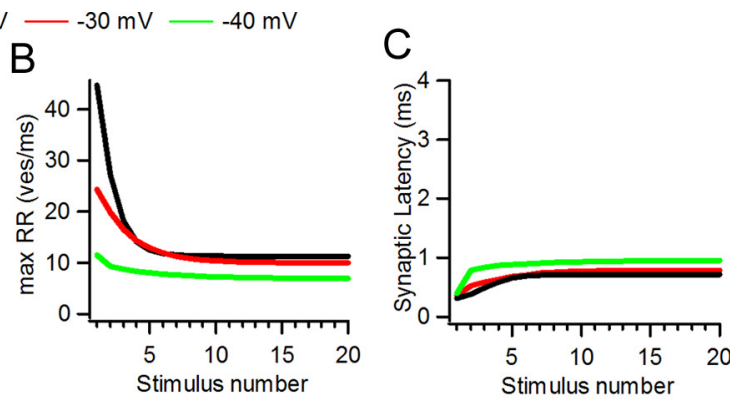

High Recovery Rate $(\tau=10 \mathrm{~ms})$
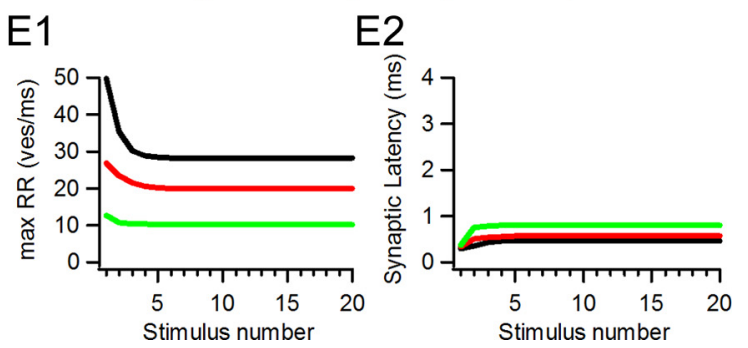

Figure 7. Computer simulations with a model of synaptic transmission at the IHC ribbon synapse. $A$, Simulated traces of release rate (bottom), idealized $\left[\mathrm{Ca}^{2+}\right]_{\mathrm{i}}$ waveform (middle), and stimulation protocol (top). Three different levels of stimulation were used and illustrated in different colors. B, Peak release rate for each stimulus showing synaptic depression. C, Synaptic latency for each pulse in the train (calculated from the onset of each pulse to the release of first vesicle). Model used for panels $\boldsymbol{A}, \boldsymbol{B}$, and $\boldsymbol{C}$ include a recovery step with a time constant of $37 \mathrm{~ms}$. D1, D2, Peak release rate and synaptic latency in a model with slow recovery rate $(\tau=1 \mathrm{~s})$. $E 1$, E2, Same as before but with an overly high recovery rate $(\tau=10 \mathrm{~ms})$.

Thus, during repeated stimulus trains, transmitter release is enhanced by stronger depolarization, but at the same time diminished by greater depletion of the available pool of vesicles. These two processes would reach a steady state dependent on the rate of pool replenishment. These assumptions were tested with a simple model of transmitter release, incorporating available data on the function of IHC release machinery (Beutner et al., 2001), a simplified pattern of $\mathrm{Ca}^{2+}$ influx based on the kinetics of $\mathrm{Ca}^{2+}$ currents (Fig. 2), and a recovery rate as measured in Figure 5.

\section{Simulating transmitter release during stimulus trains}

Transmitter release was driven by a highly cooperative model with five binding steps for $\mathrm{Ca}^{2+}$ (Beutner et al., 2001). The intracellular $\mathrm{Ca}^{2+}$ concentration used for driving release was implemented as idealized waveforms following the activation and deactivation time courses of $\mathrm{Ca}^{2+}$ currents as in Figure 2 (see Materials and Methods for details on the model). Simulations of 20 pulse trains with three different levels of stimulation are shown in Figure 7, where two main parameters were tracked: maximum release (as release rate, Fig. $7 B$ ) and synaptic latency per pulse (Fig. 7C). A scheme of the stimulus protocol, $\left[\mathrm{Ca}^{2+}\right]_{\mathrm{i}}$, and release rate are shown in the top, middle and bottom panels of Figure $7 \mathrm{~A}$. Three stimulation patterns were used to drive the model: ' -20 $\mathrm{mV}$,' ' $-30 \mathrm{mV}$,' and ' $-40 \mathrm{mV}$ ' by analogy to the experimental values. Trains at $-40 \mathrm{mV}$ and $-30 \mathrm{mV}$ had maximal release of $\sim 25 \%$ and $54 \%$, respectively, that of the $-20 \mathrm{mV}$ train $(11.4$ vesicles (ves) $/ \mathrm{ms}, 24.3 \mathrm{ves} / \mathrm{ms}$, and $44.8 \mathrm{ves} / \mathrm{ms}$, for the three train levels). At (quasi)steady state the rates were 6.9, 10.0 and 11.3 $\mathrm{ves} / \mathrm{ms}$, respectively. Average latency to the first exocytosed vesicle per pulse showed convergence between trains (Fig. 7C) (0.72 $\mathrm{ms}, 0.79 \mathrm{~ms}$, and $0.96 \mathrm{~ms}$ for the $-20 \mathrm{mV},-30 \mathrm{mV}$, and $-40 \mathrm{mV}$ trains, respectively) although the absolute values were smaller than in the experimental data (compare Figs. 2 and 6; see Discussion for possible reasons). These values differed maximally by $33 \%$ with stimulus intensities $(-20 \mathrm{mV}$ vs $-40 \mathrm{mV})$ that drive release at five-fold different rates (see peak rate in first pulse, Fig. $7 A, B)$.

The rate of vesicle pool replenishment should be important in determining the dynamics of release during stimulus trains. This was examined in the model by reducing $(\tau=1 \mathrm{~s}$, Fig. $7 D 1, D 2)$ or increasing $(\tau=10 \mathrm{~ms}$, Fig. 7E1,E2) the recovery rate. With slower pool recovery, release dropped to values close to zero in all conditions ( 0.5 vesicle/ms for $-20 \mathrm{mV}, 0.6$ vesicle/ms for $-30 \mathrm{mV}$, $1.8 \mathrm{ves} / \mathrm{ms}$ for $-40 \mathrm{mV}$ ). Latency per pulse underwent a constant increase during the course of the 20 stimuli train, reaching maximum values of: $2.7 \mathrm{~ms}$ for the $-20 \mathrm{mV}, 3.5 \mathrm{~ms}$ for the $-30 \mathrm{mV}$, and $1.7 \mathrm{~ms}$ for the $-40 \mathrm{mV}$ trains (measurements were interrupted before the end of the train at -20 and $-30 \mathrm{mV}$ because release rate dropped below threshold criteria). This behavior would degrade phase constancy. On the other hand, the rapid pool recovery rate model showed relatively constant latencies (Fig. 7E2), but steady-state release (28.4 ves/ms for the $-20 \mathrm{mV}$, $20.0 \mathrm{ves} / \mathrm{ms}$ for the $-30 \mathrm{mV}$, and $10.3 \mathrm{ves} / \mathrm{ms}$ for the $-40 \mathrm{mV}$ trains) was significantly larger than that found experimentally. Since models with altered pool recovery rates diverged significantly from experimental observations, additional work was restricted to the model parameters illustrated in Figure $7 A-C$. This simple model, which can be driven with stimuli of different intensities and includes a vesicle recovery mechanism, was able to capture the main features of the experimental results. including fairly constant synaptic latencies throughout the train.

\section{Mixed trains}

Figure $8 A$ shows the estimated size of the readily releasable pool at the end of each pulse in simulated trains at three depolarization levels. It can be clearly noted that the higher the intensity of the stimulus, the fewer vesicles were left for release after each pulse. At steady state, the $-20 \mathrm{mV}$ train operated with the smallest pool size but still released more vesicles than the other two trains (Fig. 

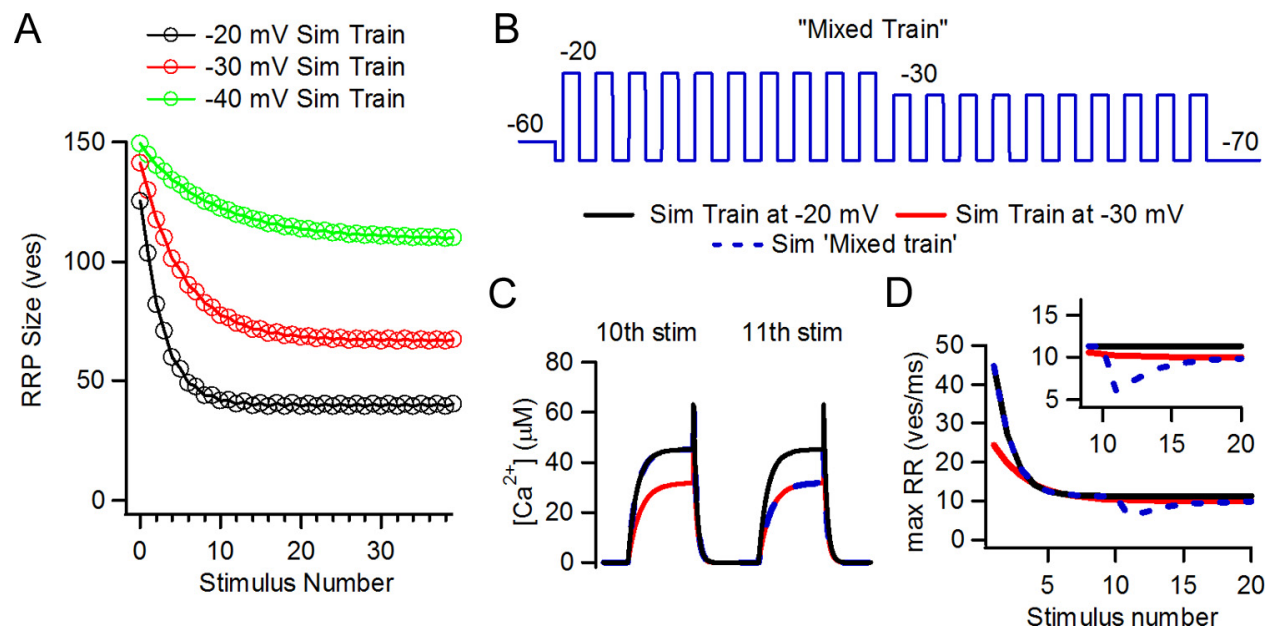

Figure 8. Equilibrium between recovery and release rate was unbalanced after changing stimulus pattern in simulations (Sim) of synaptic activity. $A$, Vesicle pool size at the end of each stimulus for the three levels. $\boldsymbol{B}$, Mixed train protocol. $\boldsymbol{C}$, Detail of 10 th and 11 th pulses in the simulated trains. In the mixed train, $\mathrm{Ca}^{2+}$ transients changed from a $-20 \mathrm{mV}$ regime to a $-30 \mathrm{mV}$ regime. $\boldsymbol{D}$, Peak release rate for the -20 and $-30 \mathrm{mV}$ trains (acting as controls) and the mixed trains. Note the transient dip in the mixed train upon switching to the $-30 \mathrm{mV}$ regime on the 11 th pulse due to alteration of the equilibrium between release drive and depression level.

$7 A, B)$. The strength of the stimulus compensated for the smaller pool size.

If in steady state a balance was reached between depletion and $\mathrm{Ca}^{2+}$ channel gating probability, it would be insightful to investigate the consequence of altering this equilibrium. The model was used to predict this effect by using 'mixed trains' in which the first 10 steps were to $-20 \mathrm{mV}$ and the last 10 were to $-30 \mathrm{mV}$ (Figs. $8 A, B$ ). Stronger depletion (at $-20 \mathrm{mV}$ ) combined with weaker calcium channel gating (at $-30 \mathrm{mV}$ ) would be expected to produce diminished vesicular release, as indeed was found (Fig. $8 D$ ). At the transition point, the release rate fell transiently before gradually rising and finally converging to that of a control ('unmixed') train at $-30 \mathrm{mV}$. Latency to release underwent a transient increase in the same time window that also recovered to control values in the following stimuli. The mixed train protocol was repeated on paired recordings from IHCs and afferent boutons. Transmitter release during mixed trains was compared to control unmixed trains at $-30 \mathrm{mV}$ and $-20 \mathrm{mV}$ (Fig. 9). EPSCs evoked during the 11th to 15 th pulses in the mixed train were compared to EPSCs in the unmixed trains (Fig. 9A, $B$, gray boxes). The average response to these five stimuli in the unmixed train was $22 \pm 2 \mathrm{pA}$, whereas in the mixed train it was $8 \pm 3 \mathrm{pA}$ ( $n=5$ and 8 cell pairs respectively, $6-58$ repetitions), showing a strong reduction in the average response (ANOVA, $p=0.003$ ) (Fig. 9C). The phase of the synaptic events occurring at the transition point between the two levels was calculated. The mixed trains showed an out of phase average compared with the control $-20 \mathrm{mV}$ trains, but not with the $-30 \mathrm{mV}$ (Fig. 9D) $(2.21 \pm 0.12$ $\mathrm{ms}, 2.75 \pm 0.11 \mathrm{~ms}, 2.52 \pm 0.10 \mathrm{~ms}$, respectively. ANOVA, $p=$ $0.0178) . \mathrm{Ca}^{2+}$ currents in the mixed train were similar to those of the unmixed trains (not shown).

The transient dip in synaptic response amplitude (release rate in the stimulations) would indicate that the proposed equilibrium between release drive and size of vesicle pool was unique for each stimulation regime favoring phase-locked responses to periodic stimuli.

\section{Discussion}

Auditory timing and $\mathrm{Ca}^{2+}$ dependence

The auditory system shows several synaptic adaptations that contribute to maintaining accurate and precise neurotransmission.
Fast kinetics of postsynaptic AMPA receptors and short membrane time constants (generally influenced by resting potassium conductances) help to abbreviate synaptic events and are therefore capable of maintaining high-frequency signaling (Trussell, 1999). On the other hand, large amplitude synaptic potentials ensure fast transitions to threshold, and with low variability.

It has been clear since early work by Bernard Katz that transmitter release is highly dependent on extracellular calcium (Katz and Miledi, 1965). Later, it was shown that postsynaptic responses are preceded by voltage-dependent $\mathrm{Ca}^{2+}$ currents and that synaptic latency is voltage (and thus $\mathrm{Ca}^{2+}$ ) dependent (Llinás et al., 1981; Felmy et al., 2003; Bollmann and Sakmann, 2005). The IHC ribbon synapse is driven by continuously varying receptor potentials, rather than action potentials, and has rate constants for vesicular release that are $\mathrm{Ca}^{2+}$ dependent (Beutner et al., 2001). Thus, it seems somewhat paradoxical that tone bursts at a fixed frequency (typically at best or characteristic frequency) evoke action potentials in auditory afferent neurons with a constant phase throughout a wide range of stimulus intensities (Galambos and Davis, 1943; Kiang et al., 1965; Rose et al., 1967; Ruggero, 1992). Since action potentials in the auditory nerve are driven by the release of neurotransmitter from the IHC (Robertson and Paki, 2002), a louder sound, producing greater hair cell depolarization and more calcium influx, should evoke more and earlier transmitter release.

\section{Phase-locking at the IHC ribbon synapse}

Considering the differences in experimental paradigms between explants of the organ of Corti (from neonatal rats) and auditory nerve recordings from anesthetized animals, we set out to investigate phase locking of neurotransmission occurring at the IHC ribbon synapse. We first observed that transmitter released from the IHC is indeed phase locked to a periodic stimulus and remains constant even as release probability changes. EPSCs from IHCs were elicited at a constant phase (or latency) by trains of square pulses or sinusoidal stimulation to different levels of depolarization (Figs. 2, 3). To our knowledge, this work shows for first time that phase constancy is a fundamental property of the IHC ribbon synapse.

We also extended recent observations indicating that this synapse would operate in a steady facilitated mode (Cho et al., 2011; Goutman and Glowatzki, 2011; Schnee et al., 2011), and we now 
show that facilitation produces a significant increase in accuracy and precision throughout the operating range of the synapse (Fig. 4). Responses to single steps at different potentials $(-40,-30$, or -20 $\mathrm{mV}$ ) still showed differences in latency (Fig. 4C, black symbols), which is consistent with a $\mathrm{Ca}^{2+}$-dependent process as shown in ribbon (Heidelberger et al., 1994; Beutner et al., 2001) and regular chemical synapses (Neher and Sakaba, 2008).

The single pulse data may also depart from the nanodomain model in which the IHC ribbon synapse would operate (Brandt et al., 2005; Graydon et al., 2011). According to this model, the opening of a single $\mathrm{Ca}^{2+}$ channel is sufficient to trigger the release of a tightly colocalized vesicle(s). Under this scenario, the $\mathrm{Ca}^{2+}$ concentration at the vesicular sensor would be saturating, and release latency (and probability) would be highly determined by the gating properties of the $\mathrm{Ca}^{2+}$ channels. However, whereas $\mathrm{Ca}^{2+}$ currents activated by pulses to -20 and $-40 \mathrm{mV}$ differed in activation kinetics by $\sim 200 \mu \mathrm{s}$ (Fig. 4E2), release latencies to the same pulses were 1.55 or $3.70 \mathrm{~ms}$ apart (with or without predepolarization, respectively, Fig. 4C). It is still possible that the opening of few channels (not strictly one) are necessary to trigger release (Brandt et al., 2005), but future investigations will help determine precisely the release mechanism at this synapse.

We also observed that at the end of a train of stimuli, an additional depolarization revealed the level of depression that was reached by the train (Fig. 6). With this protocol, trains of higher intensity produced more profound levels of depression and, consistently, weaker trains presented higher responsiveness. How might this behavior affect response timing during a train? It is reasonable to think that a given stimulus in a train promotes and accelerates release by allowing $\mathrm{Ca}^{2+}$ into the cell, but at the same time it provokes partial vesicle depletion. It has been shown recently that latency to the first exocytotic event is inversely correlated with vesicle pool size (also between jitter and size) (Wittig and Parsons, 2008). Therefore, we propose that the partial depletion provoked by a given pulse slows release to the following stimuli. As a consequence, a competing dynamic would be established in which larger depolarization produces faster release due to larger $\mathrm{Ca}^{2+}$ influx, but simultaneously delays subsequent release by depleting the available vesicle pool. It is still necessary to determine the linkage between recovery and different phases of synaptic adaptation (Relkin and Doucet, 1991; Ruggero, 1992) and also whether depression at this synapse is produced by simple vesicle depletion, clearance of release sites, or some other mechanism (Neher, 2010).

Finally, we would like to propose that an equilibrium would be established between the level of depolarization in a train and the average size of the vesicle pool on which stimuli operate. In an ongoing train with large depolarizations, release would operate on a relatively smaller pool (due to stronger depression produced by the stimulus), whereas trains with weaker depolarizations would function on a larger one. Simulations allow us to track the size of the pool during a given stimulation protocol, and differences in number of vesicles were actually observed (Fig. 8A). Moreover, results in Figures 8 and 9 confirm this hypothesis; when a low intensity train operates in a context of a small vesicle pool due to strong depletion (the transition point in the mixed train), the synapse departs from equilibrium and shows a significant drop in release rate. It is important to note that auditory nerve responses to decrements in tonal intensity show very similar transient dips in firing rate (Smith et al., 1985). In simulations, a concomitant transient increase in latency at the transition point, followed by return to control unmixed values, was also observed. This modeling prediction was only partially observed experimentally, as a significant difference was observed in the phase of synaptic responses in the mixed train compared with the $-20 \mathrm{mV}$ trains but not with the $-30 \mathrm{mV}$ ones. As release dropped so dramatically at the transition point (Fig. $9 \mathrm{~B}, \mathrm{C}$ ), it is possible that the few events left for analysis were insufficient for a complete comparison (2-22 events in the 11 th to 15 th cycles, $n=$ 8 recordings). It is important to note that an ahead phase as observed in the mixed train (Fig. 9D) does not mean that release is faster but rather that latencies are changed and phase is not conserved.

\section{Simulations}

Several studies have presented models of synaptic transmission that successfully represented experimental results at central synapses (Dittman and Regehr, 1998; Weis et al., 1999; Saviane and Silver, 2006; Hosoi et al., 2007). Recovery in all these studies is 
critical for determining the strength of the synapse and has been repeatedly modeled as a $\mathrm{Ca}^{2+}$-dependent process. Modeling efforts were also undertaken to investigate the dynamics of vesicle pools and transmission timing at the hair cell ribbon synapse (Beutner et al., 2001; Schnee et al., 2005; Wittig and Parsons, 2008). The present model shows features that are shared with those studies, including a $\mathrm{Ca}^{2+}$ sensor model derived from $\mathrm{Ca}^{2+}$. uncaging experiments to drive release (Beutner et al., 2001), idealized intracellular $\mathrm{Ca}^{2+}$ transients following the kinetics of the currents measured in Figures 2 and 6 (Weis et al., 1999; Beutner et al., 2001), and a recovery process as studied in Figure 5 (see Materials and Methods for details on the model). The latter feature assumes that only a partial depletion of the vesicle pool was produced during the trains.

Simulations in Figure 7 show that this simple model is able to capture the basic characteristics of IHC ribbon function during trains of stimuli, such as intensity coding, phase locking, and the tight relation between timing precision and efficient recovery. As shown in the model, a low recovery rate produces increasing synaptic latency during the train. In contrast, fast recovery provides good timing but excessive sustained release that does not match the results obtained in these recordings from the immature cochlea.

Discrepancies in the absolute values of latency between simulations and experimental results may arise from processes that are not contemplated in the model, such as diffusion of $\mathrm{Ca}^{2+}$ in the cytosol, other putative $\mathrm{Ca}^{2+}$-dependent processes, vesicle translocation, vesicle fusion to the plasma membrane, diffusion of glutamate, and activation of postsynaptic receptors.

Finally, this model strengthens the idea that phase locking is primarily determined by an equilibrium between release drive and pool size, conferring a constant synaptic latency throughout the train. It cannot be precluded, though, that additional mechanism(s) not taken into account in this model might contribute as well to improve phase locking. This issue deserves special attention, as for instance some differences in latency persisted when comparing different train levels (Fig. 7C).

\section{Functional consequences}

Phase locking has been extensively shown in different species with diverse hearing frequency ranges. In every case, this property degrades as the stimulation frequency increases above $1-5 \mathrm{kHz}$ (Kiang et al., 1965; Rose et al., 1967; Taberner and Liberman, 2005). In species with poor low-frequency sensitivity, such as mice and rats, few auditory nerve neurons respond to pure tones below or within this range (Taberner and Liberman, 2005). However, it has also been shown that phase locking occurs when high-frequency sounds are modulated in amplitude by a low-frequency envelope (Buran et al., 2010) with several common characteristics (Yin, 2002).

It is useful to compare the degree of phase locking (or synchronization) that was reached in synaptic responses with that of auditory nerve recordings in vivo. It has been reported in auditory nerve recordings from rats that vector strength (a measure of synchronization that ranges from 0 to 1 ) decreases with frequency and also that it is larger at higher intensities of stimulation (Paolini et al., 2001). The value of vector strength calculated in the current study, $\sim 0.4$, is in the range of values reported for auditory nerves, but it is also important to consider that few fibers with characteristic frequency (or best frequency) below $1 \mathrm{kHz}$ are found in rats. In low-frequency hearing animals such as cats, auditory nerves present higher synchronization values (Johnson, 1980). Provided that the experiments in the current study were done at room temperature and with an immature organ of Corti, it is expected that better synchronization would be obtained in more physiological conditions.

The mechanism proposed in the current study is based on general phenomena such as the dynamics of vesicle pools, synaptic plasticity, and the characteristics of the receptor potential with variable amplitudes at the hair cells. However, these experiments were performed in the apical coil of neonatal rats, and thus the conclusions should not be immediately extrapolated to the in vivo situation. Future studies on mature endorgans and/or in species with higher sensitivity to low-frequency components $(<1 \mathrm{kHz})$ should be done to confirm whether our model can be generalized to other synapses.

\section{References}

Avissar M, Furman AC, Saunders JC, Parsons TD (2007) Adaptation reduces spike-count reliability, but not spike-timing precision, of auditory nerve responses. J Neurosci 27:6461-6472. CrossRef Medline

Beurg M, Michalski N, Safieddine S, Bouleau Y, Schneggenburger R, Chapman ER, Petit C, Dulon D (2010) Control of exocytosis by synaptotagmins and otoferlin in auditory hair cells. J Neurosci 30:13281-13290. CrossRef Medline

Beutner D, Voets T, Neher E, Moser T (2001) Calcium dependence of exocytosis and endocytosis at the cochlear inner hair cell afferent synapse. Neuron 29:681-690. CrossRef Medline

Bollmann JH, Sakmann B (2005) Control of synaptic strength and timing by the release-site $\mathrm{Ca}^{2+}$ signal. Nat Neurosci 8:426-434. CrossRef Medline

Brandt A, Striessnig J, Moser T (2003) CaV1.3 channels are essential for development and presynaptic activity of cochlear inner hair cells. J Neurosci 23:10832-10840. Medline

Brandt A, Khimich D, Moser T (2005) Few CaV1.3 channels regulate the exocytosis of a synaptic vesicle at the hair cell ribbon synapse. J Neurosci 25:11577-11585. CrossRef Medline

Buran BN, Strenzke N, Neef A, Gundelfinger ED, Moser T, Liberman MC (2010) Onset coding is degraded in auditory nerve fibers from mutant mice lacking synaptic ribbons. J Neurosci 30:7587-7597. CrossRef Medline

Cho S, Li GL, von Gersdorff H (2011) Recovery from short-term depression and facilitation is ultrafast and $\mathrm{Ca}^{2+}$ dependent at auditory hair cell synapses. J Neurosci 31:5682-5692. CrossRef Medline

Dittman JS, Regehr WG (1998) Calcium dependence and recovery kinetics of presynaptic depression at the climbing fiber to Purkinje cell synapse. J Neurosci 18:6147-6162. Medline

Felmy F, Neher E, Schneggenburger R (2003) Probing the intracellular calcium sensitivity of transmitter release during synaptic facilitation. Neuron 37:801-811. CrossRef Medline

Frank T, Khimich D, Neef A, Moser T (2009) Mechanisms contributing to synaptic $\mathrm{Ca}^{2+}$ signals and their heterogeneity in hair cells. Proc Natl Acad Sci U S A 106:4483-4488. CrossRef Medline

Frank T, Rutherford MA, Strenzke N, Neef A, Pangršič T, Khimich D, Fetjova A, Gundelfinger ED, Liberman MC, Harke B, Bryan KE, Lee A, Egner A, Riedel D, Moser T (2010) Bassoon and the synaptic ribbon organize $\mathrm{Ca}^{2+}$ channels and vesicles to add release sites and promote refilling. Neuron 68:724-738. CrossRef Medline

Fuchs PA (2005) Time and intensity coding at the hair cell's ribbon synapse. J Physiol 566:7-12. CrossRef Medline

Galambos R, Davis H (1943) The response of single auditory nerve fiber to acoustic stimulation. J Neurophysiol 6:39-58.

Glowatzki E, Fuchs PA (2002) Transmitter release at the hair cell ribbon synapse. Nat Neurosci 5:147-154. CrossRef Medline

Goldberg JM, Brown PB (1969) Response of binaural neurons of dog superior olivary complex to dichotic tonal stimuli: some physiological mechanisms of sound localization. J Neurophysiol 32:613-636. Medline

Goutman JD, Glowatzki E (2007) Time course and calcium dependence of transmitter release at a single ribbon synapse. Proc Natl Acad Sci U S A 104:16341-16346. CrossRef Medline

Goutman JD, Glowatzki E (2011) Short-term facilitation modulates size and timing of the synaptic response at the inner hair cell ribbon synapse. J Neurosci 31:7974-7981. CrossRef Medline

Grant L, Fuchs P (2008) Calcium- and calmodulin-dependent inactivation 
of calcium channels in inner hair cells of the rat cochlea. J Neurophysiol 99:2183-2193. CrossRef Medline

Graydon CW, Cho S, Li GL, Kachar B, von Gersdorff H (2011) Sharp Ca(2) nanodomains beneath the ribbon promote highly synchronous multivesicular release at hair cell synapses. J Neurosci 31:16637-16650. CrossRef Medline

Griesinger CB, Richards CD, Ashmore JF (2005) Fast vesicle replenishment allows indefatigable signalling at the first auditory synapse. Nature 435: 212-215. CrossRef Medline

Heidelberger R, Heinemann C, Neher E, Matthews G (1994) Calcium dependence of the rate of exocytosis in a synaptic terminal. Nature 371:513515. CrossRef Medline

Hosoi N, Sakaba T, Neher E (2007) Quantitative analysis of calciumdependent vesicle recruitment and its functional role at the calyx of Held synapse. J Neurosci 27:14286-14298. CrossRef Medline

Johnson DH (1980) The relationship between spike rate and synchrony in responses of auditory-nerve fibers to single tones. J Acoust Soc Am 68: 1115-1122. CrossRef Medline

Johnson CP, Chapman ER (2010) Otoferlin is a calcium sensor that directly regulates SNARE-mediated membrane fusion. J Cell Biol 191:187-197. CrossRef Medline

Johnson SL, Marcotti W, Kros CJ (2005) Increase in efficiency and reduction in $\mathrm{Ca}^{2+}$ dependence of exocytosis during development of mouse inner hair cells. J Physiol 563:177-191. CrossRef Medline

Katz B, Miledi R (1965) The effect of calcium on acetylcholine release from motor nerve terminals. Proc R Soc Lond B Biol Sci 161:496-503. CrossRef Medline

Keen EC, Hudspeth AJ (2006) Transfer characteristics of the hair cell's afferent synapse. Proc Natl Acad Sci U S A 103:5537-5542. CrossRef Medline

Kiang NYS, Watanabe T, Thomas EC, Clark LF (1965) Discharge patterns of single fibers in the cat's auditory nerve. In: MIT Research Monograph 35, pp 1-151. Cambridge, MA: MIT.

Li GL, Keen E, Andor-Ardó D, Hudspeth AJ, von Gersdorff H (2009) The unitary event underlying multiquantal EPSCs at a hair cell's ribbon synapse. J Neurosci 29:7558-7568. CrossRef Medline

Liberman MC (1980) Morphological differences among radial afferent fibers in the cat cochlea: an electron-microscopic study of serial sections. Hear Res 3:45-63. CrossRef Medline

Llinás R, Steinberg IZ, Walton K (1981) Presynaptic calcium currents in squid giant synapse. Biophys J 33:289-321. CrossRef Medline

Marcotti W, Johnson SL, Rusch A, Kros CJ (2003) Sodium and calcium currents shape action potentials in immature mouse inner hair cells. J Physiol 552:743-761. CrossRef Medline

Moser T, Beutner D (2000) Kinetics of exocytosis and endocytosis at the cochlear inner hair cell afferent synapse of the mouse. Proc Natl Acad Sci U S A 97:883-888. CrossRef Medline

Moser T, Brandt A, Lysakowski A (2006) Hair cell ribbon synapses. Cell Tissue Res 326:347-359. CrossRef Medline

Neher E (2010) What is rate-limiting during sustained synaptic activity: vesicle supply or the availability of release sites. Front Synaptic Neurosci 2:144. CrossRef Medline

Neher E, Sakaba T (2008) Multiple roles of calcium ions in the regulation of neurotransmitter release. Neuron 59:861-872. CrossRef Medline

Nouvian R, Beutner D, Parsons TD, Moser T (2006) Structure and function of the hair cell ribbon synapse. J Membr Biol 209:153-165. CrossRef Medline

Pangrsic T, Lasarow L, Reuter K, Takago H, Schwander M, Riedel D, Frank T, Tarantino LM, Bailey JS, Strenzke N, Brose N, Müller U, Reisinger E, Moser T (2010) Hearing requires otoferlin-dependent efficient replenishment of synaptic vesicles in hair cells. Nat Neurosci 13:869-876. CrossRef Medline
Paolini AG, FitzGerald JV, Burkitt AN, Clark GM (2001) Temporal processing from the auditory nerve to the medial nucleus of the trapezoid body in the rat. Hear Res 159:101-116. CrossRef Medline

Relkin EM, Doucet JR (1991) Recovery from prior stimulation. I: Relationship to spontaneous firing rates of primary auditory neurons. Hear Res 55:215-222. CrossRef Medline

Robertson D, Paki B (2002) Role of L-type $\mathrm{Ca}^{2+}$ channels in transmitter release from mammalian inner hair cells. II. Single-neuron activity. J Neurophysiol 87:2734-2740. Medline

Rose JE, Brugge JF, Anderson DJ, Hind JE (1967) Phase-locked response to low-frequency tones in single auditory nerve fibers of the squirrel monkey. J Neurophysiol 30:769-793. Medline

Roux I, Safieddine S, Nouvian R, Grati M, Simmler MC, Bahloul A, Perfettini I, Le Gall M, Rostaing P, Hamard G, Triller A, Avan P, Moser T, Petit C (2006) Otoferlin, defective in a human deafness form, is essential for exocytosis at the auditory ribbon synapse. Cell 127:277-289. CrossRef Medline

Ruggero MA (1992) Physiology and coding of sound in the auditory nerve. In: The mammalian auditory pathway: neurophysiology (Fay RR, Popper AN, eds), pp 34-93. New York: Springer.

Russell IJ, Sellick PM (1978) Intracellular studies of hair cells in the mammalian cochlea. J Physiol 284:261-290. Medline

Safieddine S, Wenthold RJ (1999) SNARE complex at the ribbon synapses of cochlear hair cells: analysis of synaptic vesicle- and synaptic membraneassociated proteins. Eur J Neurosci 11:803-812. CrossRef Medline

Saviane C, Silver RA (2006) Fast vesicle reloading and a large pool sustain high bandwidth transmission at a central synapse. Nature 439:983-987. CrossRef Medline

Schnee ME, Lawton DM, Furness DN, Benke TA, Ricci AJ (2005) Auditory hair cell-afferent fiber synapses are specialized to operate at their best frequencies. Neuron 47:243-254. CrossRef Medline

Schnee ME, Santos-Sacchi J, Castellano-Muñoz M, Kong JH, Ricci AJ (2011) Calcium-dependent synaptic vesicle trafficking underlies indefatigable release at the hair cell afferent fiber synapse. Neuron 70:326-338. CrossRef Medline

Schneggenburger R, Forsythe ID (2006) The calyx of Held. Cell Tissue Res 326:311-337. CrossRef Medline

Smith RL, Brachman ML, Frisina RD (1985) Sensitivity of auditory-nerve fibers to changes in intensity: a dichotomy between decrements and increments. J Acoust Soc Am 78:1310-1316. CrossRef Medline

Spassova MA, Avissar M, Furman AC, Crumling MA, Saunders JC, Parsons TD (2004) Evidence that rapid vesicle replenishment of the synaptic ribbon mediates recovery from short-term adaptation at the hair cell afferent synapse. J Assoc Res Otolaryngol 5:376-390. CrossRef Medline

Taberner AM, Liberman MC (2005) Response properties of single auditory nerve fibers in the mouse. J Neurophysiol 93:557-569. Medline

Trapani JG, Obholzer N, Mo W, Brockerhoff SE, Nicolson T (2009) Synaptojanin 1 is required for temporal fidelity of synaptic transmission in hair cells. PLoS Genet 5:e1000480. CrossRef Medline

Trussell LO (1999) Synaptic mechanisms for coding timing in auditory neurons. Annu Rev Physiol 61:477-496. CrossRef Medline

Weis S, Schneggenburger R, Neher E (1999) Properties of a model of $\mathrm{Ca}(++)$-dependent vesicle pool dynamics and short term synaptic depression. Biophys J 77:2418-2429. CrossRef Medline

Wittig JH Jr, Parsons TD (2008) Synaptic ribbon enables temporal precision of hair cell afferent synapse by increasing the number of readily releasable vesicles: a modeling study. J Neurophysiol 100:1724-1739. CrossRef Medline

Yin TCT (2002) Neural mechanisms of encoding binaural localization cues in the auditory brainstem. In: Integrative functions in the mammalian auditory pathway (Oertel D, Fay RR, ed), pp 99-159. New York: Springer. 